\title{
Title: Bridging science and traditional knowledge to assess cumulative impacts of stressors on ecosystem health
}

Authors: Chrystal S. Mantyka-Pringle ${ }^{a, *}$, Timothy D. Jardine ${ }^{a, b}$, Lori Bradford ${ }^{c}$, Lalita Bharadwaj $^{c}$, Andrew P. Kythreotis ${ }^{\mathrm{d}, \mathrm{e}}$, Jennifer Fresque-Baxter ${ }^{\mathrm{f}}$, Erin Kelly ${ }^{\mathrm{f}}$, Gila Somers ${ }^{\mathrm{f}}$, Lorne E. Doig ${ }^{\mathrm{b}}$, Paul D. Jones ${ }^{\mathrm{b}}$, Karl-Erich Lindenschmidt ${ }^{\mathrm{a}} \&$ the Slave River and Delta Partnership ${ }^{\mathrm{g}}$

\section{Affiliations:}

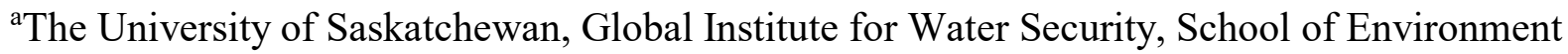
and Sustainability, Saskatoon, SK S7N 5B3, Canada.

${ }^{\mathrm{b}}$ The University of Saskatchewan, Toxicology Centre, School of Environment and Sustainability, Saskatoon, SK S7N 5B3, Canada

${ }^{\mathrm{c}}$ The University of Saskatchewan, School of Public Health, Saskatoon, SK S7N 5B3, Canada. ${ }^{\mathrm{d}}$ Cardiff School of Geography and Planning and Sustainable Places Research Institute, Glamorgan Building, Cardiff University, King Edward VII Ave, Cardiff, CF10 3WA, Wales ${ }^{\mathrm{e} T}$ Tyndall Centre for Climate Change Research, Zuckerman Institute for Connective Environmental Research, School of Environmental Sciences, University of East Anglia, Norwich, NR4 7TJ, UK fDepartment of Environment \& Natural Resources, Government of the Northwest Territories, Yellowknife, NT X1A 2L9, Canada

${ }^{\mathrm{g}} \mathrm{A}$ partnership representing the community members living along the Slave River and delta and local and territorial authorities and Federal agencies with responsibilities for the management of the system.

T. Jardine (tim.jardine@usask.ca); L. Bradford (lori.bradford@usask.ca); L. Bharadwaj (lalita.bharadwaj@usask.ca); A. Kythreotis (KythreotisA@cardiff.ac.uk); J. Fresque-Baxter (Jennifer_Fresque-Baxter@gov.nt.ca); E. Kelly (Erin_Kelly@gov.nt.ca); G. Somers (Gila Somers@gov.nt.ca); K. Lindenschmidt (karl-erich.lindenschmidt@usask.ca); L. Doig (lorne.doig@usask.ca); P. Jones (paul.jones@usask.ca)

*Correspondence author. Email: c.mantyka-pringle@usask.ca; Telephone: +1 3062034224

\begin{abstract}
Cumulative environmental impacts driven by anthropogenic stressors lead to disproportionate effects on indigenous communities that are reliant on land and water resources. Understanding and counteracting these effects requires knowledge from multiple sources. Yet the combined use of Traditional Knowledge (TK) and Scientific Knowledge (SK) has both technical and philosophical hurdles to overcome, and suffers from inherently imbalanced power dynamics that can disfavour the very communities it intends to benefit. In this article, we present a 'two-eyed seeing' approach for co-producing and blending knowledge about ecosystem health by using an adapted Bayesian Belief Network for the Slave River and Delta region in Canada's Northwest Territories. We highlight how bridging TK and SK with a combination of field data, interview transcripts, existing models, and expert judgment can address key questions about ecosystem health when considerable uncertainty exists. SK indicators (e.g., bird counts, mercury in fish, water depth) were graded as moderate, whereas TK indicators (e.g., bird usage, fish aesthetics, changes to water flow) were graded as being poor in comparison to the past. SK indicators were predominantly spatial (i.e.,
\end{abstract}


43 comparing to other locations) while the TK indicators were predominantly temporal (i.e., 44 comparing across time). After being populated by 16 experts (local harvesters, Elders, 45 governmental representatives, and scientists) using both TK and SK, the model output reported 46 low probabilities that the social-ecological system is healthy as it used to be. We argue that it is 47 novel and important to bridge TK and SK to address the challenges of environmental change such 48 as the cumulative impacts of multiple stressors on ecosystems and the services they provide. This 49 study presents a critical social-ecological tool for widening the evidence-base to a more holistic 50 understanding of the system dynamics of multiple environmental stressors in ecosystems and for 51 developing more effective knowledge-inclusive partnerships between indigenous communities, 52 researchers and policy decision-makers. This represents new transformational empirical insights 53 into how wider knowledge discourses can contribute to more effective adaptive co-management 54 governance practices and solutions for the resilience and sustainability of ecosystems in Northern 55 Canada and other parts of the world with strong indigenous land tenure.

56 Keywords: traditional knowledge, integration, multiple stressors, Bayesian belief network, 57 adaptive co-management, social-ecological systems 


\section{INTRODUCTION}

\subsection{Complementary use of traditional knowledge and science} There have been persistent calls for greater inclusion of local and indigenous or traditional knowledge (TK) alongside conventional scientific knowledge (SK) in making decisions about natural resources (e.g., Huntington, 2000; Mistry and Berardi, 2016; Sutherland et al., 2014). Such a call is ensconced within three wider transdisciplinary movements that intersect knowledge use and decision-making for environmental management. First, there is an increasing shift towards adaptive co-management in social-ecological systems, defined as the use of different types of local stakeholder and rights-holder knowledge to collaboratively foster diverse forms of knowledge generation (Berkes, 2009; Olsson et al., 2004). Second, hierarchical management is being rejected for more democratic management and governance of non-linear and complex environmental issues (Chaffin et al., 2014; Stringer et al., 2006). Last, there is a recognized need to move away from narrow and linear conventions of technical expertise that marginalises TK through its use of particular reductionist forms of SK in formulating ecosystem, biodiversity and environmental change decision-making and policies (Beck, 2011; Pielke, 2007; Turnhout et al., 2016). This paper empirically contributes to the debates by operationalizing the integration and complementarity of TK and SK for environmental and natural resources decision-making.

The idea of 'interplay', how new knowledge interacts with other forms of knowledge, has been highlighted as one important factor in driving more effective knowledge use for adaptive comanagement governance (Lemos, 2015). TK, which refers to the knowledge, innovations and practices of indigenous and local communities that are developed, sustained and passed on from generation to generation, can provide complementary perspectives, borne from long periods of shared observation and experimentation that are often lacking in SK (Sutherland et al., 2014). Both SK and TK can be empirically driven, but TK generally has a highly qualitative element as well. TK is more oral, holistic and requires much face-to-face interaction whereas SK is more reductionist, lab or field-based and requires specialized skills or technology for monitoring. Both forms of knowledge can independently provide powerful insights into understanding ecosystem health, but both can also suffer from the inability to recognise or detect environmental changes (e.g., Bender et al., 2013; Moller et al., 2004). There is abundant literature examining the use of TK with SK for guiding adaptive processes in conservation and resource management (e.g., Berkes et al., 2000; Moller et al., 2004). For example, certain jurisdictions within Canada, Australia and Brazil are taking steps forward in the bridging of scientific monitoring data and traditional local observations for the conservation of threatened species and protected areas (Berkes et al., 2000; Gerhardinger et al., 2009), in managing forestry practices (Pinkerton, 1998), water management strategies (GNWT, 2010; GA and GNWT, 2016), and to inform climate change mitigation, adaptation and policy (Leonard et al., 2013). Co-production of TK and SK can also enhance capacity in rural or vulnerable communities observing resource declines, allow new ideas and tools to improve both local and scientific practices, and provide checks and balances to ensure new ideas are acceptable in terms of customary institutions and values (Johnson et al., 2016; Reid et al., 2006).

Despite these advantages, the combined use of TK and SK for environmental management is often challenging and problematic. There are fundamental differences in the way people perceive the nature of knowledge and tensions can arise in part because of disparate power relations and lack of collaboration between indigenous people and researchers (e.g., Bohensky et al., 2013; Nadasdy, 
1999) that leads to only a fractional representation of the complete body of knowledge held in TK (Houde, 2007). This issue can be strengthened by the co-production of research by communities and scientists that leads to the emergence of more inclusive and resilient forms of environmental governance when abrupt changes caused by multiple environmental stressors loom (Folke et al., 2005). Co-production, however, is also affected by other diverse factors such as the politics of indigenous rights and indigenous socioeconomic and cultural differences (Hill et al., 2012). Academic and governmental practices generally require TK to fit within a scientific management system even though the knowledges held by indigenous peoples can be fundamentally different from those held by scientists (i.e., oral vs. written, compartmentalized vs. holistic) (Armitage et al., 2011). Some scientists have even rejected TK as being 'anecdotal', 'biased' and 'inaccurate' (Brook and McLachlan, 2008). Many works therefore continue to advocate the use of TK and its problematic 'integration' with science without describing or even proposing practical means for achieving this goal (Reid et al., 2006).

\subsection{Bayesian belief networks as a two-eyed seeing approach}

The concept of 'two-eyed seeing' offers a framework on how different types of knowing such as TK and SK can be brought together more often as a developmental practice (Briggs, 2013), while respecting the differences and perspectives that each can offer (Bartlett et al., 2012). As a result, we learn to see from one eye with the strengths of TK, and from the other eye with the strengths of SK. Using both eyes together brings us closer to a more improved understanding of the dynamics of the whole system under multiple stressors both abrupt and long-term (Folke et al., 2005); a new, balanced way of seeing the world that has been created for the benefit of all (Whyte et al., 2015).

Bayesian Belief Networks (BBNs) are one type of participatory modelling (i.e., Barber and Jackson, 2015) in which a two-eyed seeing approach can be embraced and operationalized. BBNs are probabilistic models that provide a graphical representation of key factors and interactions for an outcome of interest (Kjaerulff and Madsen, 2008). Key factors are represented as nodes (parent and child) in the diagram and their dependencies on other key factors, and the outcome of interest, are depicted as directed links to form a directed acyclic graph (Jensen, 1996). A conditional probability table (CPT) is used to describe the probability of each value of the child node, conditioned on every possible combination of values of its parent nodes (Marcot et al., 2006). The information used to populate the CPTs in the network may originate from diverse sources such as empirical data, expert opinion (e.g., TK) and simulation outputs, and can be a combination of quantitative and qualitative data (e.g., Mantyka-Pringle et al., 2014; Martin et al., 2015). Thus, BBNs have been increasingly applied to complex social-ecological problems such as the evaluation of alternative management options for natural systems under multiple stressors (Ban et al., 2014; Mantyka-Pringle et al., 2016), in adaptive management (Nyberg et al., 2006), and for representing TK in SK-based ecosystem management (McGregor et al., 2010).

In this paper, we show how a two-eyed seeing BBN can create a shared understanding of change in an ecosystem that is under cumulative environmental impacts: the Slave River Delta (SRD) in the Northwest Territories (NWT) of Canada. A BBN approach was selected for this study because the method is arguably ideally suited for bridging TK with SK. It provides an intuitive means of exploring system dynamics, and does not have to be explicitly represented at a common scale (Marcot et al., 2006). The SRD offers a useful case study to examine BBNs as a tool for blending TK and SK to address concerns arising from rapid and long-term environmental change (e.g., 
Schindler and Smol, 2006). Like many other regions of the world (e.g., Ferreira et al., 2014; Mantyka-Pringle et al., 2015; Obidzinski et al., 2012), these effects are felt most strongly in communities that remain dependent on natural resources for subsistence, livelihoods or cultural practices. Cumulative effects are often individually minor but can become collectively significant in ecosystems over space and time (Schindler, 2001; Segner et al., 2014), and these effects can be difficult to detect using conventional SK approaches because of the short-term nature of the instrumental record (e.g., Schwalb et al., 2014). Indigenous people in northern Canada are responding to environmental change through the development of new institutional arrangements with stakeholders, government agencies, and researchers for the co-production of knowledge (Davidson-Hunt et al., 2013b). Our broad aim was therefore to present a theoretical and preliminary BBN for understanding the cumulative environmental impacts of multiple stressors on the SRD ecosystem, including both social and ecological consequences.

\section{BACKGROUND}

The Slave River is the largest transboundary river in the NWT of Canada (Fig. 1). It draws its flow from catchments located in the provinces of Alberta, British Columbia and Saskatchewan. Thus, the quality of Slave River water and sediment is substantially influenced by environmental conditions and anthropogenic activities that take place upstream of the NWT. The Slave River serves as a direct source of drinking water for the people and wildlife residing along its shores. It also provides habitat for many wildlife species that are hunted, fished and trapped by Northerners. Traditional foods, including fish, waterfowl and mammals are vital to the indigenous way of life, and are reported to make up between 5-33\% of local harvester's diet (Halseth, 2015). In 201391.8 $\%$ of households in Fort Resolution and $73.9 \%$ in Fort Smith (two Slave River communities) indicated they had consumed meat or fish obtained from hunting or fishing (NWTBS, 2016).

The SRD lies at the outflow of the Slave River, in the southcentral portion of Great Slave Lake. Biological productivity in the SRD depends on continuous depositing of fresh sediment (English et al., 1997) and periodic flooding (Brock et al., 2008) that occurs during ice-jams in the spring. The SRD provides important habitat for numerous species of mammals, fish and waterfowl, and is indispensable to surrounding indigenous communities economically, socially, and culturally.

The Slave River basin has experienced increased resource development activity over the last several decades. Predominant industrial activities include oil and gas developments, oil sands operations, pulp and paper mills, coal and uranium mining, agriculture, and forestry (Pembina Institute, 2016). Further, the W.A.C. Bennett Dam, a hydroelectric development on the Peace River in northern British Columbia, exists upstream of the Slave River watershed. As these upstream developments have the potential to affect water resources, Northerners have raised concerns about impacts on the Slave River. In addition, the Slave River is undergoing further transformation due to climate change (Schindler and Smol, 2006). Concerns and questions about the quantity and quality of the water, and ultimately the health of wildlife and people who drink the water, are especially relevant in the SRD, given the subsistence lifestyle and the close connection to the land and water still prevalent today among indigenous people residing along the Slave River.

In response to community concerns about the health of the ecosystem in the SRD (Cash et al., 2000; Wolfe et al., 2007), the Slave River and Delta Partnership (SRDP) was created in 2010. The 
SRDP is a collaboration of First Nations, Métis, communities and agencies and organizations working, managing and living along the Slave River. Partners include three First Nations, three Métis organizations, territorial government and federal government agencies, the Town of Fort Smith and Hamlet of Fort Resolution and a college and research institute. Formation of the SRDP stemmed from development of Northern Voices, Northern Waters: NWT Water Stewardship Strategy ('the Strategy'), which was collaboratively developed with Northerners. During Strategy development, community partners identified the need for locally-driven, community-based research and monitoring, and building capacity at the local level to meaningfully participate.

In partnership with the SRDP, a community-based monitoring program was developed to support communities to collect, interpret and use a system of environmental indicators to assess the cumulative effects of stressors on the SRD. The program was designed to provide information to help answer three key questions raised by the SRD community: (1) Is the water safe to drink? (2) Are the fish and wildlife safe to eat?, and (3) is the ecosystem healthy?

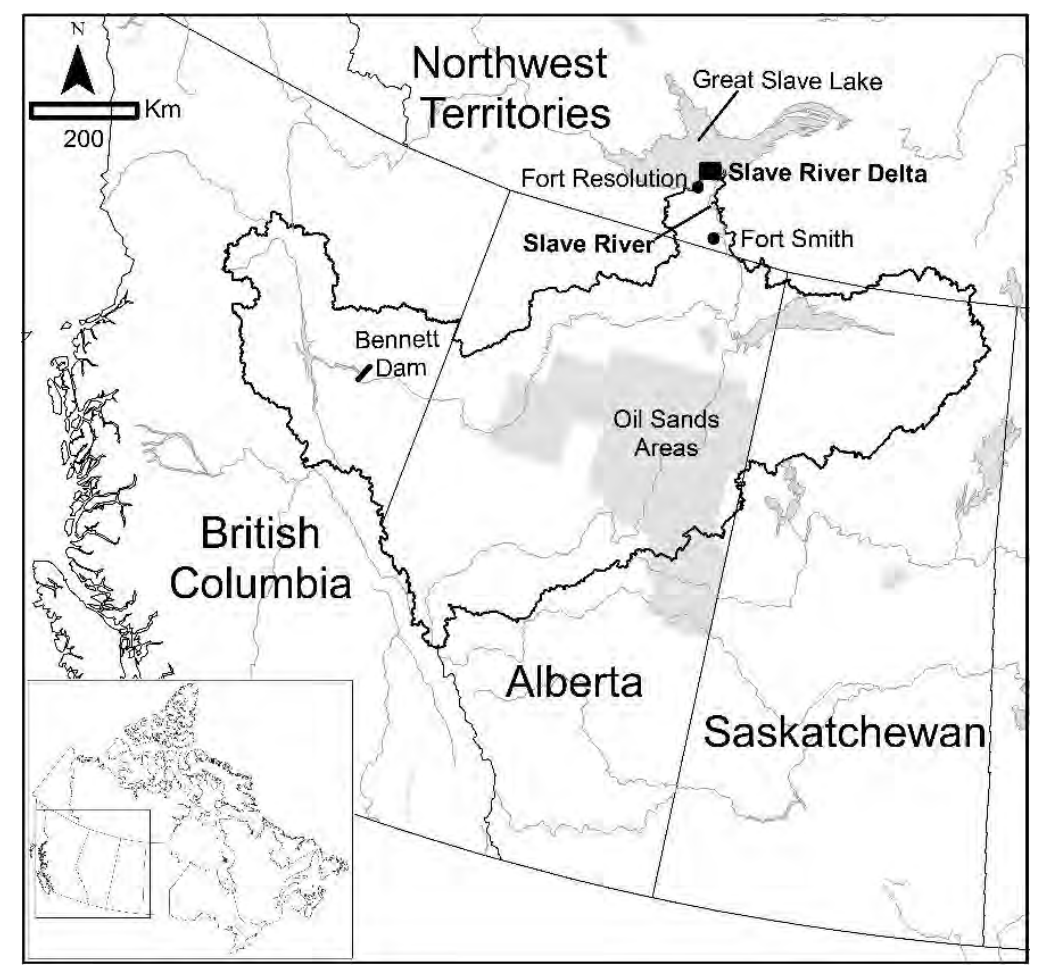

Fig. 1. Map of the Slave River and Delta region showing the boundary of the Slave River Basin and the location of the Bennett Dam and oil sands development upstream with insert positioning the region relative to the rest of Canada.

\section{MATERIAL AND METHODS}

\subsection{Indicators and data sources}

With the three guiding questions in mind, physical (e.g., water level), chemical (e.g., chemical residues in fish), biological (e.g., muskrat populations) and TK (e.g., changes in fish usage) 
indicators were chosen based on a two-day workshop held in March 2011 attended by more than 100 people from the SRD community to provide input on the monitoring of regional ecosystem health (AANDC and GNWT-ENR, 2012). Over the course of two years, 41 indicators (22 qualitative TK and 19 quantitative SK) were selected and refined to represent the key ecosystem health indicators that could be used to measure and monitor the health of the SRD (Table 1; see Appendix A for a full description of indicators). Indicators that were correlated with others (e.g., water temperature and dissolved oxygen under ice; number of bird species and bird usage; Ephemeroptera, Plecoptera and Trichoptera species richness and invertebrate taxa richness) were removed to reduce the effect of collinearity. Other science indicators including macroinvertebrate invasive species, plant invasive species and air quality were excluded due to lack of data.

TK was gathered respectfully through one-to-one interviews with a total of 11 Elders from the two partner communities throughout 2014 (Bradford and Bharadwaj, 2015) under research ethics and community approval (University of Saskatchewan REB 13-165 and Aurora Research Institute License No. 15383). Interview questions focused on elicitation of information about socialecological changes over time and comparisons of current experiences in relation to the past. Measures of water quality and quantity, fish health, aquatic invertebrate sampling, ice condition, wildlife health and counts were collected via a combination of field observations and document reviews during 2011-2015 (see Appendix B for a summary of data collection and sources).

Table 1. List of indicators selected for Bayesian Network Model. Complete description of indicators are provided in Appendix A.

\begin{tabular}{|c|c|}
\hline Traditional Knowledge Indicators & Scientific Knowledge Indicators \\
\hline \multicolumn{2}{|c|}{ Water Quality } \\
\hline Water vitality, Physical appearance of water & $\begin{array}{c}\text { Turbidity, Polycyclic aromatic hydrocarbons (PAHs), } \\
\text { Dissolved phosphorus (DP), Metals }\end{array}$ \\
\hline \multicolumn{2}{|c|}{ Fish Health } \\
\hline Fish usage, Fish aesthetics & $\begin{array}{l}\text { Fish external anomalies, Fish internal anomalies, } \\
\text { Fish bile PAHs, Fish mercury }\end{array}$ \\
\hline \multicolumn{2}{|c|}{ Wildlife Health } \\
\hline Mammal usage, Mammal aesthetics & Muskrat mercury, Moose stress \\
\hline \multicolumn{2}{|c|}{ Water Quantity } \\
\hline Flood extent, Water flow & Water depth, Flow regime \\
\hline \multicolumn{2}{|c|}{ Food Webs } \\
\hline Plant usage, Invasive plants & $\begin{array}{l}\text { Invertebrate density, Invertebrate taxa richness } \\
\text { Shannon Wiener index }\end{array}$ \\
\hline \multicolumn{2}{|c|}{ Wildlife Populations } \\
\hline Bird usage, Bird aesthetics & Bird abundance \\
\hline \multicolumn{2}{|c|}{ Social Change } \\
\hline \multicolumn{2}{|l|}{ Cultural changes, Storytelling, Animal ethics } \\
\hline \multicolumn{2}{|c|}{ Livelihood } \\
\hline Ecotourism, Harvesting, Travel, Adaptation & Fur-bearer abundance \\
\hline \multicolumn{2}{|c|}{ Ice Regime } \\
\hline
\end{tabular}


Length of ice period, Ice significance, Air pocket density
Ice thickness, Dissolved oxygen (DO)

concentration under ice

\subsection{Model construction and expert elicitation}

The intent of the BBN was to link the TK and SK indicators together to assess cumulative environmental impacts. We adhered to the guidelines proposed by Marcot et al. (2006) when developing the BBN. First, a conceptual model was constructed to identify the major causal links between the indicators and the three guiding questions (Fig. 2). Nine indices of water quality, fish health, wildlife health, water quantity, ice regime, food webs, wildlife populations, social change and livelihoods were used to group the indicators before feeding into the three questions. The conceptual model was then converted into a BBN using Netica software (Norsys Software Corporation, 2008). The BBN consists of independent (parent) and dependent (child) nodes, and the links (arrows) represent how the nodes are related. Underlying each child node is a conditional probability table (CPT) that specifies the probability of each state conditional on other nodes (Jensen, 1996; Marcot et al., 2006). The thresholds defining states for each parent node (indicator) were determined by either expert knowledge, published guidelines, or by using the 5th and 95th percentile values of each data set via consultation with Elders and freshwater scientists and managers who were familiar with the study region (see Appendix A). Child nodes were categorized into three alternative states of low, medium or high for the nine indices, or yes, don't know and no for the three questions. SRDP representatives requested these child node states so that they would be easy to understand by the community. A BBN was chosen to model this system because of its ability to model interactions within the CPTs, and integrate empirical data with expert knowledge (Mantyka-Pringle et al., 2014; Martin et al., 2015). The model framework was presented to a range of indigenous representatives and experts in aquatic ecology and management that either had experience within the SRDP, or locally on the land to ensure that applicable indices and states had

257 been included. 


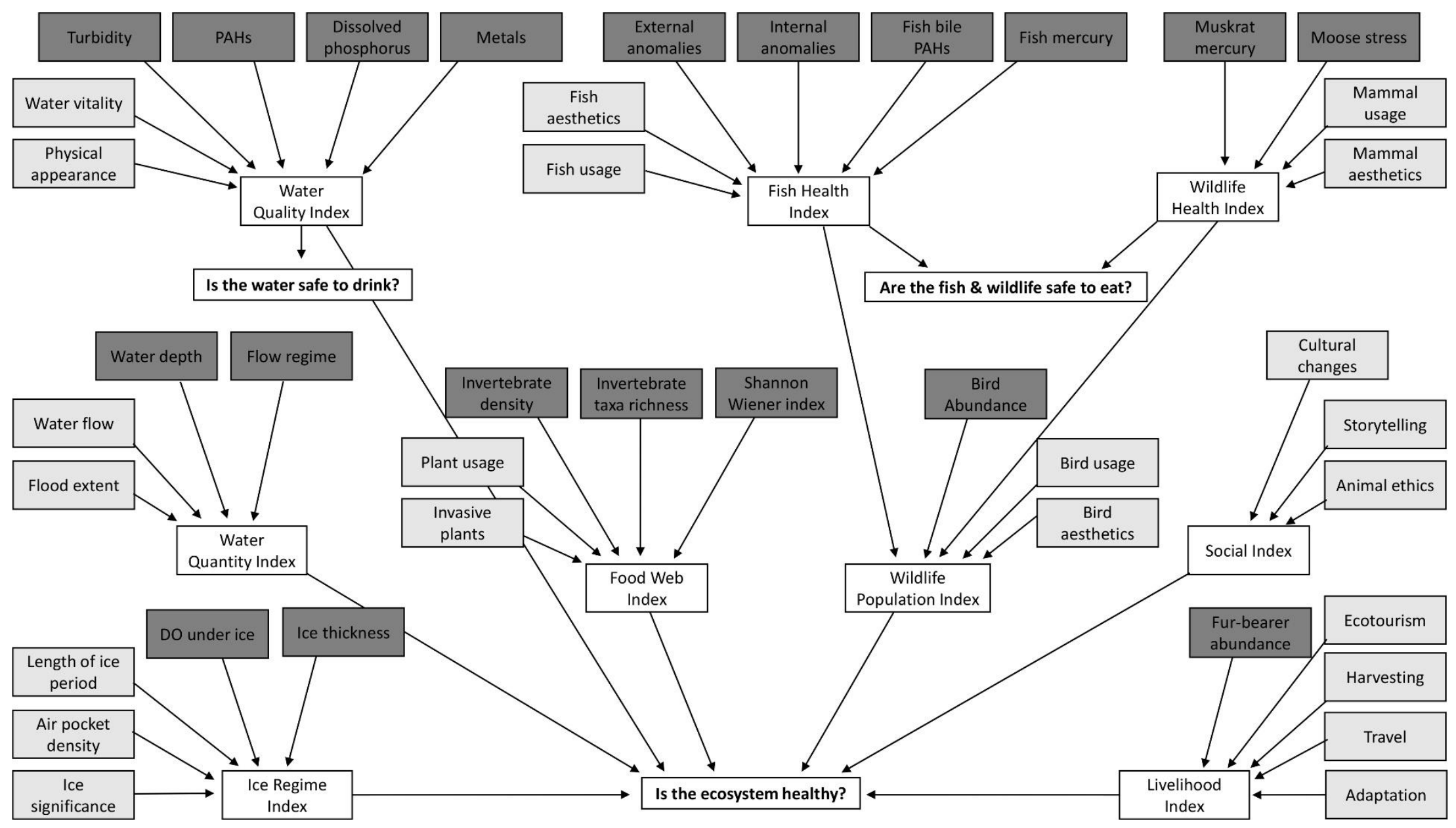

259 Fig. 2. Conceptual model of the key SRD ecosystem health indicators that interact to address the three questions of interest: (1) Is the water safe 260 to drink? (2) Are the fish and wildlife safe to eat?, and (3) is the ecosystem healthy? Light grey nodes were informed by traditional knowledge; 261 dark grey nodes were informed by scientific data; white nodes were our response indices and questions of interest. Arrows indicate the links 262 between nodes. 
Experts ${ }^{1}$ were approached to take part in an expert elicitation procedure to assist in populating the CPTs of the BBN (9 indices and 3 question nodes) and effectively weight the importance of each indicator. This is a common approach and best practice when empirical data for specific nodes/relationships are absent (Ban et al., 2014; Martin et al., 2012). We invited nominations for individuals that held different types of knowledge (local harvesters, Elders, governmental representatives, and scientists) to participate in either of two workshops held in Fort Smith and Fort Resolution, NWT in May 2015. Experts with a strong knowledge of the land and the wildlife and who were familiar with ongoing science assessments in the region were nominated by their indigenous or community group. Sixteen experts with a breadth of knowledge regarding fish and wildlife health, social and livelihood factors, and water quality and quantity attended. An equal number of Elders (4), local harvesters (4), government staff (4) and scientists (4; 2 social scientists and 2 biophysical scientists) were chosen to reduce the bias that may be associated with the experts' perceptions and cultural views.

A facilitated group discussion of the BBN and the indicators/indices in question was undertaken. For each index, and with no knowledge of the actual TK and SK data gathered during the program, workshop participants were asked a series of permutated hypothetical questions such as what is the likelihood that wildlife health is low, medium or high given that muskrat mercury and moose stress are low, moderate or high; mammal usage is less, same or more; and mammal aesthetics is worse, same or better? In light of research done by others suggesting that multiple modalities for introducing and collecting data enhance collaboration and cultural safety (Ball and Janyst, 2008; Schnarch, 2004), we used combined visual, narrative, and textual tools during the expert elicitation as opposed to singular methods (e.g., Kuhnert et al., 2010). A series of images were presented to the experts (see Appendix C) to assist them with remembering the different combinations of states/indicators for each scenario. Detailed information on the specific meaning and states of each indicator (see Appendix A) and how they were collected (see Appendix B) were discussed verbally and presented in a document format. Experts were then given two coloured markers and were asked to make independent estimates of the conditional probabilities in the form of 10 coloured dots drawn on a scale of 1 to 10 for each index (low $=1$ to 3.5 ; medium $=3.5$ to 7.5 ; high $=7.5$ to 10 ; see Appendix D). This exercise was repeated for the question nodes (no $=1$ to 3.5 ; don't know $=3.5$ to 7.5 ; yes $=7.5$ to 10 ) with CPTs being populated based on combinations of states of the indices. These methods provided measures of uncertainty by requesting experts to provide upper and lower confidence dots as well as their best estimate dot imagining the range that their uncertainty estimate may fall between. An attempt to de-bias the responses was made by explaining the bias towards overconfidence as well as the importance of scenario-based role-playing before the survey began. Some indicators may be linked with outside influences. For example, 'Travel' (the transition from dog sleds and canoes) may be linked to technological advances rather than a direct link to the environment. Experts were asked to disregard these influences when

\footnotetext{
${ }^{1}$ Given that effective adaptive governance of social-ecological systems requires a whole system dynamics approach, our definition of expertise bridges the notion of 'cultural rationality' with technical knowledge, thus cutting away from the sole institutionalisation of conventional forms of technical scientific expertise based on reductionism and determinism that often seeks to separate its knowledge from the culture in which it is produced (Fischer, 2000). 'Experts' are those specialists in their relevant academic fields; governance systems; or in the knowledge organization, production, or generation on site and with respect to surviving and thriving in an ecological, social, spiritual, economic, or cultural system. For example, scientists conduct research and publish their knowledge formally; Elders are considered experts in the cultural practices and knowledge generation and translation of their people; local harvesters are considered experts in understanding relationships among living things existing in their ecosystems.
} 
estimating the CPTs. Experts were also asked to rank their level of expertise (little knowledge, some knowledge or top expert) for each index and response question. The group then reconvened and discussed these independent judgements. Experts were then invited to revise their initial estimates (if desired) based on the group discussion by drawing 10 new dots with a different coloured marker (see Appendix D for an example).

Expert elicitation surveys were converted into probabilities by measuring the placement of each dot on the scale of 1 to 10 . We present the collated results as individual expert box plots to display the diversity and commonalities of opinions among knowledge holders on the SRD ecosystem health (Fig. 3). This demonstrates the trends, uncertainty and variance in opinions. The number of dots per state and scenario were counted and each expert was given an equal weighting in the calculation of a group mean. Cain's (2001) CPT calculator was then used to generate the full CPTs using the experts' averaged elicited probabilities. The CPT calculator works by reducing the number of scenarios in a CPT to key anchoring points which are then interpolated to complete the entire table. To run the BBN, the mean values of the empirical field datasets and the average responses of the Elders from interviews were calculated for the $19 \mathrm{SK}$ indicators and $22 \mathrm{TK}$ indicators. We originally intended to split the datasets into several case files to allow for the BBN to run multiple times to determine the output CPTs. However, comparable monitoring sites and sampling years did not exist among all the science indicators (see Appendix B). In Netica, averages were instead incorporated into the parent nodes and the new dependent node CPTs were quantified. Experts then reviewed the model to examine model behaviour.

It is important to note that since both TK and SK indicators are used to characterize the three guiding questions as shown in Fig. 2, the results represent a combined and interdependent assessment of: quantity and quality of fish, wildlife, water, ice; and changing social factors. A hypothetical yes, no or don't know response does not indicate a standardized classification based on health and safety guidelines, but rather reflects the experts' view of each question dependent on the interpretations of traditional knowledge over a lifespan as well as scientific data. Subjectivity is inherent in the assessment (Wiegmann, 2005).

\subsection{Sensitivity analysis}

After testing the model to confirm that it behaved in accordance with known situations and expert knowledge, sensitivity analysis of the model was performed (Johnson et al., 2013). This is a vital part of the evaluation process due to the amount of expert knowledge incorporated within the BBN. Entropy reduction was used to determine which indicators were the most influential in terms of their effect on child nodes (indices and response questions). Entropy reduction measures the sensitivity of changes in probabilities of child nodes when parameters and inputs were changed within the BBN (Marcot et al., 2006). Thus, a larger value for entropy reduction represents a greater influence on the probability of SRD environmental health increasing or declining and causes the biggest change in the outcome of the three guiding questions.

\section{RESULTS}

\subsection{Responses among different knowledge holders}

Elders ranked themselves as 'top experts' more than any other knowledge holder. Government representatives and scientists generally only assessed themselves as a 'top expert' in their own management area or research discipline, whereas local harvesters assessed themselves as having 'some knowledge' across all indices and questions. Scientists and government 
representatives felt they had 'little knowledge' about social change and livelihoods, whereas Elders considered they had 'little knowledge' about food webs. For the other indices and questions, the majority of experts ranked themselves as having 'some knowledge'. Experts that assessed themselves as a 'top expert' provided higher probabilities with less uncertainty in comparison to when they ranked themselves as having less expertise (i.e., gave lower probabilities with more uncertainty). No other discernible trends were observed among responses and the experts' assessments of their expertise.

354

355

356

357

Differences in the spread of responses for experts are illustrated in Fig. 3 for question 1, is the water safe to drink? In this question, for the hypothetical best-case scenario (when all parent nodes were in positive states), experts 1, 4 and 6 ( 2 local harvesters and 1 Elder) provided lowest estimate ranges (Fig. 3a), whereas for the worst-case scenario (when all parent nodes were in negative states) experts 9 and 10 (1 Elder and 1 government representative) provided slightly higher estimate ranges than other experts (Fig. 3b). For both scenarios, the remaining expert responses had ranges that at least partly overlapped. Similar response patterns were observed for questions 2 (are the fish and wildlife safe to eat?) and 3 (is the ecosystem healthy?), and for the various indices. Experts 13 and 16 (1 scientist and 1 Elder) had consistently high levels of confidence (i.e. limited range) across surveys. Some experts occasionally drew upper and lower confidence dots outside the range of their best-case and worst-case scenario. These dots were considered outliers and were removed from further analyses as they provided inconsistent probabilities and would have caused computing errors within the BBN. Given the similarity between the best case and worst-case scenario estimates for experts 1,4 and 6 , and the difficulty these experts expressed role-playing from their reality during the expert workshops, we decided to run the BBN twice. First, using all 16 experts and again with only the other 13 experts' averaged CPTs to compare the outputs and assess the sensitivity of expert judgement (see section 4.1).
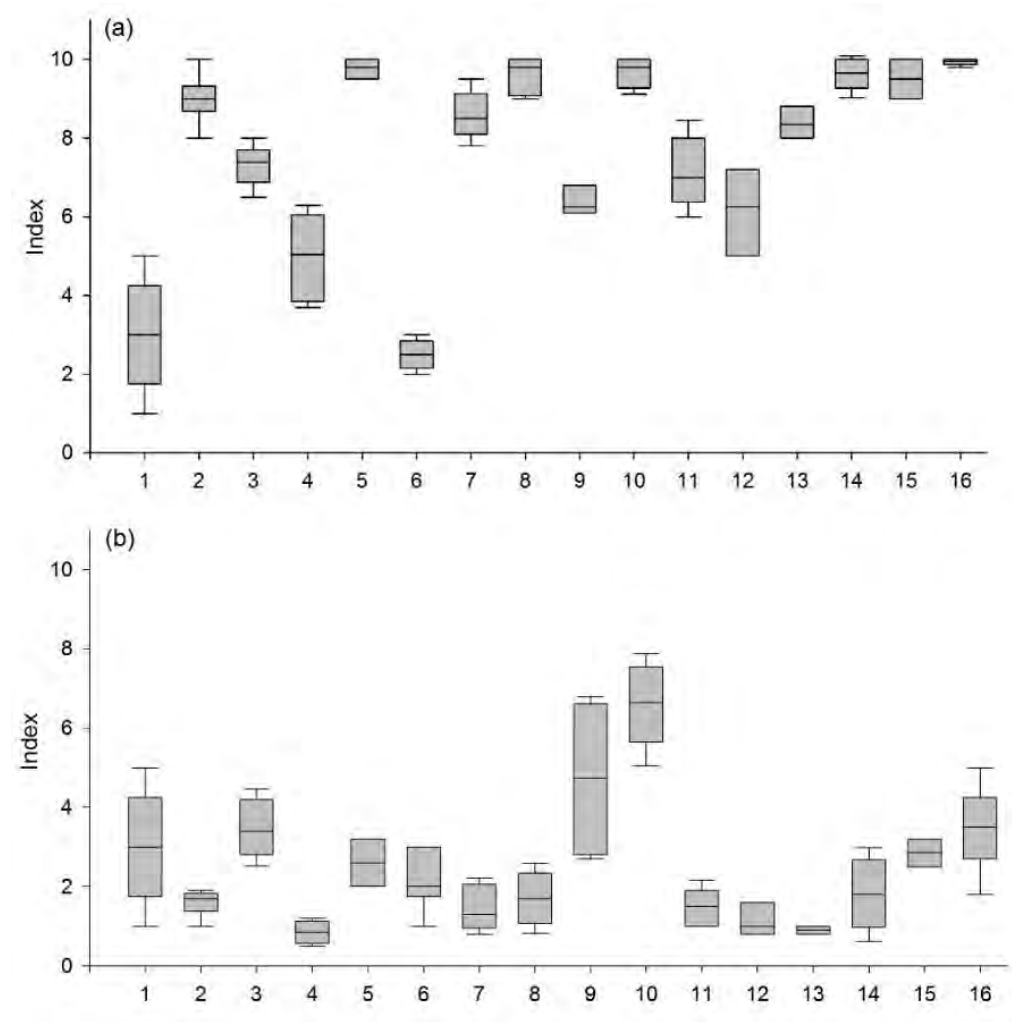
Fig. 3. Example of the spread of responses for question 1 (is the water safe to drink?), best-case (a) and worst-case scenario (b) for the experts $(n=16)$. Each box-plot represents the views of an individual expert; the error bars indicate the expert's $5 \%$ and $95 \%$ confidence bounds, the box spans the $25 \%$ and $75 \%$ confidence bounds, and the central line is the experts 'best estimate'. Expert numbers 1, 4, 7 and 16 are local harvesters; 6, 9, 11 and 15 are Elders; 2, 8, 12 and 13 are scientists, and; 3, 5, 10 and 14 are government representatives. The $y$-axes is a response index defined as 1 to $3.5=$ no, 3.5 to $7.5=$ don't know, and 7.5 to $10=$ yes.

\subsection{SRD environmental health assessment}

Data from long-term water quality monitoring in the Slave River at Fort Smith show that turbidity, dissolved and total metals, phosphorus and PAHs are below established guidelines (CCME, 1999). However, many of the TK holders interviewed report that the appearance and vitality of the water is worse compared with the past. Together, the BBN computed a higher probability (61\%) that the SRD water quality is medium for this index (Fig. 4a). Changes to the flow regime, largely due to the W.A.C. Bennett Dam on the upper Peace River, have decreased spring and summer peak flows and increased winter flows. TK holders have observed lower flows and smaller spring ice-jam floods. Together, the BBN gave similar probabilities that the water quantity index is low or medium, with only a $1 \%$ probability of being high (Fig. $4 \mathrm{~b}$ ). Potential saturation of water with air under ice leading to a larger number of air pockets that create hazards, an average ice period, thick winter ice and a reduced significance of the ice in seasonal events resulted in a higher probability of the ice regime index being low or medium, with only a $1 \%$ probability that it is high (Fig. $4 \mathrm{c}$ ).

Data on internal and external anomalies and PAHs in fish bile, and on fish mercury show moderate values for these indicators. TK states that the aesthetics and numbers of fish have declined over time. Together, this resulted in a higher probability $(66 \%)$ that the fish health index is low in comparison to other states (Fig. 4d). Mercury concentrations in muskrats were low and moose hair samples were of insufficient size to allow analysis of cortisol concentrations so equal probabilities were given for all states in this latter node. TK holders state that wildlife are fewer and in worse condition. Together, the BBN computed a higher probability ( $58 \%)$ that the wildlife health is medium for this index (Fig. 4e). Moderate numbers of waterfowl observed with time lapse cameras, coupled with local observations of fewer birds in worse condition and low fish health and medium wildlife health led to a slightly higher probability that the wildlife population index is low rather than medium, with only a $3 \%$ probability of it being high (Fig. 4f). Standard measures of invertebrate indicators of health (abundance and diversity) gave moderate values, while observations of more invasive plants and less use of traditional medicines because of changes to the wetlands of the Delta where specific plants grew resulted in a higher probability that the food web index is medium (62\%) (Fig. 4g).

Large cultural changes, poorer animal ethics and loss of knowledge transmission due to infrequent storytelling resulted in a high probability that the social index is low (Fig. 4h). Furbearer abundance (number of muskrats trapped) are moderate, while local ability to travel and adapt to changes in climate and lifestyle means less harvesting and similar engagement in ecotourism relative to the past. Together, the BBN gave a higher probability $(61 \%)$ that livelihood is scored medium for this index (Fig. 4i).

Based on this collective information, the probability distribution for Question 1 (is the water safe to drink?) resulted in $18 \%, 46 \%$ and $36 \%$ of yes, don't know and no states, respectively (Fig. 4j). For Question 2 (are the fish and wildlife safe to eat?), the BBN calculated 7\%, 43\% 
and 50\% probabilities for yes, don't know and no states, respectively (Fig. 4k). For Question 3, (is the ecosystem healthy?), these probabilities were 1\%, 45\% and 54\%, respectively.

When we compare the probabilities of the BBN with (Fig. 4) and without the three inconsistent experts' estimates (see Appendix E), we discover higher probabilities (62-66\%) that the ice regime and wildlife population indices are both medium. We also observe an 11-13\% increase in the 'don't know' probabilities for Question 1 and Question 3 in comparison to other states. No other significant changes were observed.

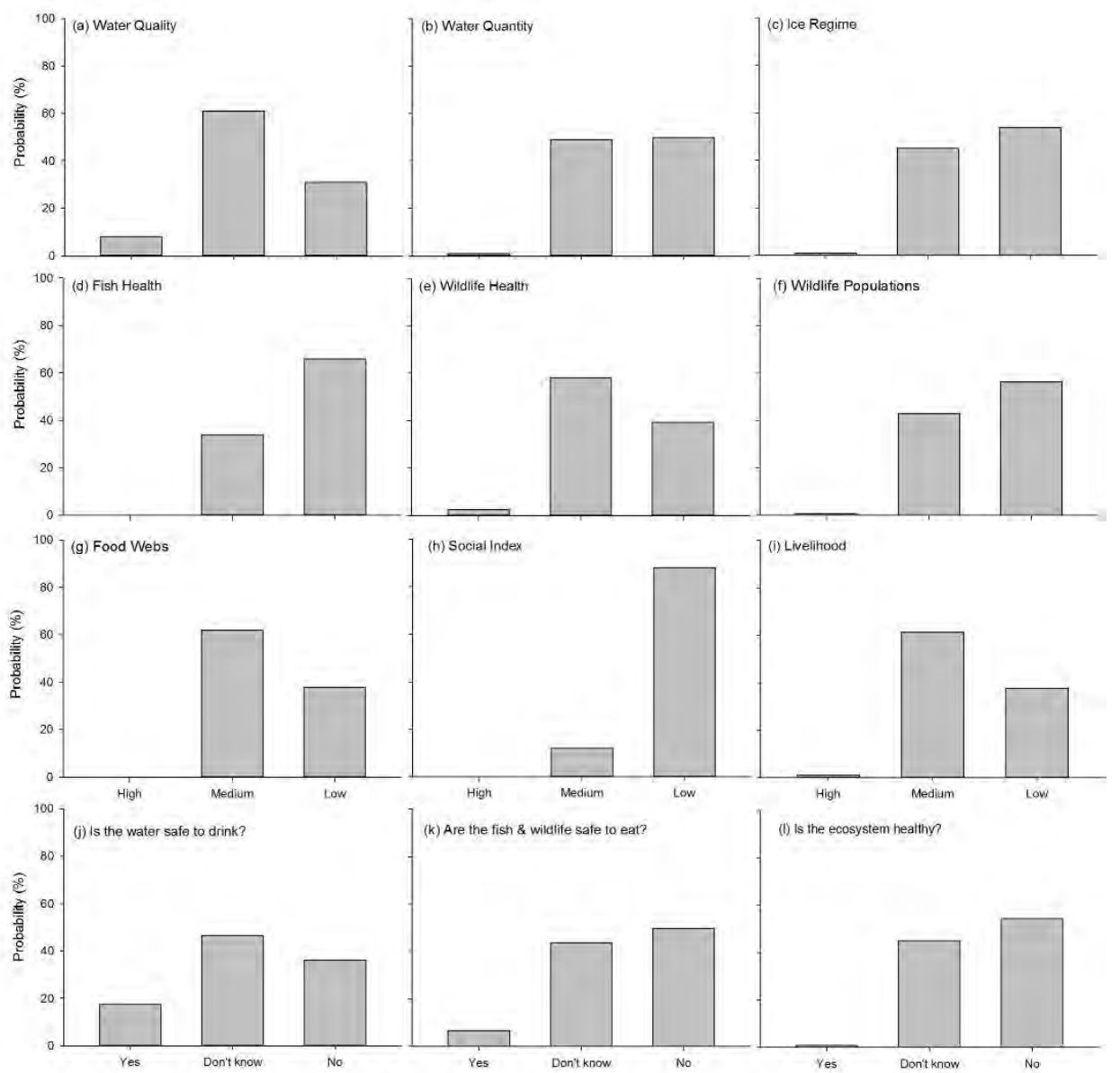

Fig. 4. Percent probabilities of the nine SRD environmental health indices $(a-i)$ and the three guiding questions $(\mathrm{j}-1)$ by the BBN model. The probabilities for this BBN were populated with 16 experts that assessed 19 science based indicators and 22 traditional knowledge indicators.

\subsection{Model sensitivity}

The sensitivity of the ecosystem health indicators to the nine indices and the three guiding questions reflects the expert judgement weightings involved in constructing the CPTs. For the water quality index, PAHs followed by metals and water vitality were the most important indicators influencing this node (Fig. 5a). Fish mercury and to a lesser extent internal anomalies were the key determinants of the fish health index (Fig. 5b). Flow regime and water depth were the most influential indicators for the water quantity index (Fig. 5c). The wildlife health index was driven by muskrat mercury and to a lesser extent mammal aesthetics (Fig. 5d), whereas the ice regime index was influenced most by ice thickness followed by the length of ice period (Fig. $5 \mathrm{e})$. The food web index was equally influenced by invertebrate taxa richness, invertebrate density and the Shannon Wiener index (Fig. 5f). The social index was most sensitive to animal 
ethics and storytelling (Fig. 5g), whereas the livelihood index was most sensitive to harvesting

442 and fur-bearer abundance (Fig. 5h). Wildlife health followed by fish health indices primarily influenced both the wildlife population index (Fig. 5i) and Question 2 (are the fish and wildlife safe to eat?; Fig. 5j). For Question 1 (is the water safe to drink?), the water quality index was the most dominant feature influencing this node (Fig. 5k). For Question 3 (is the ecosystem healthy?), the combination of water quality, social change, water quantity, and wildlife population indices was the most important set of factors affecting change (Fig. 51). There were no differences in the sensitivity of findings when the three inconsistent experts' CPTs were 449 removed from the BBN. 

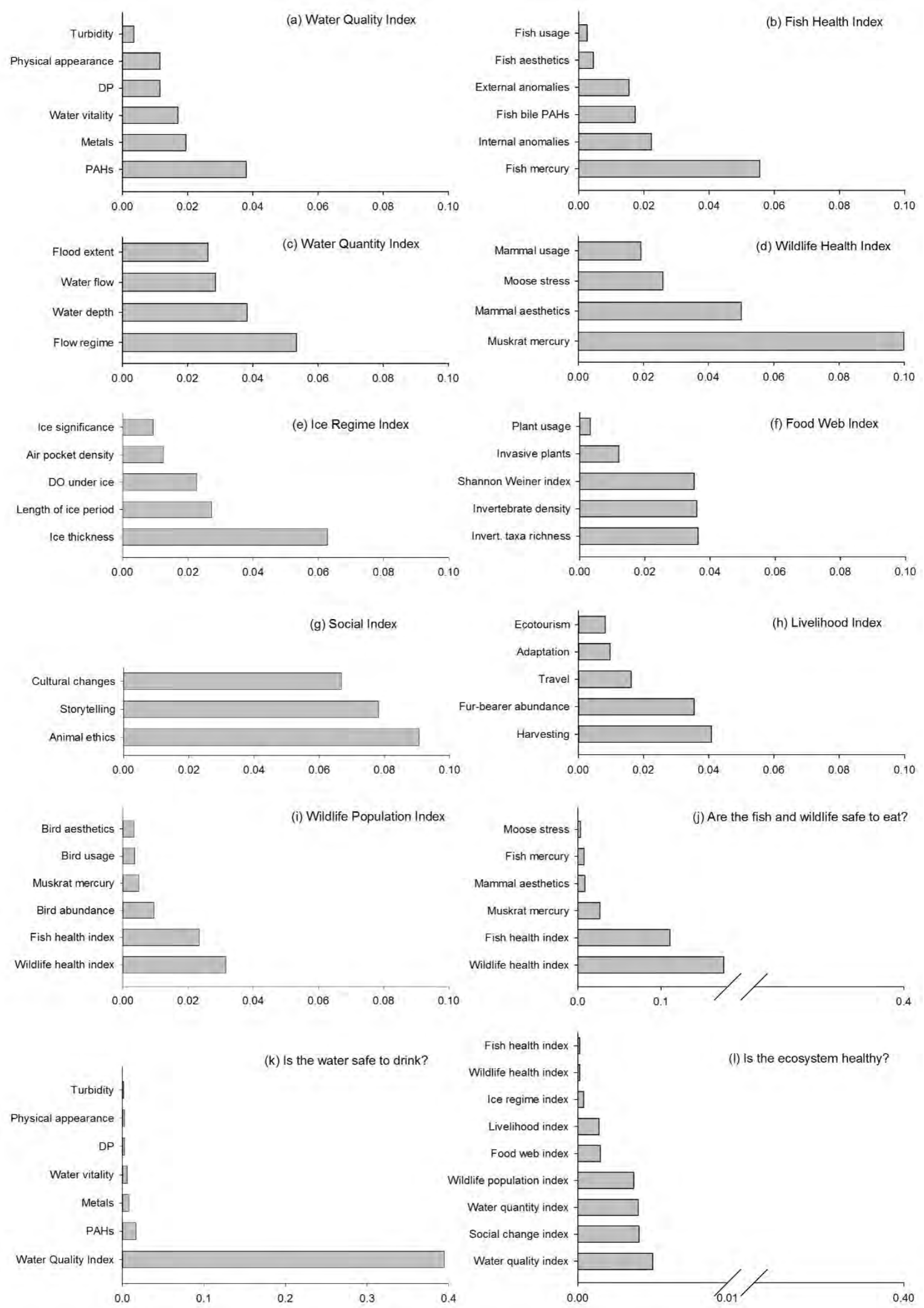

451 Fig. 5. Sensitivity of each index $(a-i)$ and guiding question $(j-1)$ to key ecosystem health 452 indicators/indices included in the BBN. Values are expressed using entropy reduction, which is 453 a measure of how much findings at one node can influence the beliefs in another. 


\section{DISCUSSION}

\subsection{Moving beyond simple integration}

TK is often 'integrated' with SK for sustaining natural resources (e.g., Leonard et al., 2013; Moller et al., 2004), but may disadvantage indigenous peoples and cause power imbalances between indigenous knowledge systems and outside forces when attempting integration (Berkes, 2012; Johnson et al., 2016). Understanding how to bridge these knowledge systems rather than 'integrating' them remains a major gap in the practical application of adaptive and environmental co-management of social-ecological systems research. Repeated calls have, therefore, been made for a more nuanced typology of methods and governance that allows for multi-level indigenous engagement in more formalised environmental management contexts (e.g., Hill et al., 2012; Mistry and Berardi, 2016; Reid et al., 2006). The empirical application of a two-eyed seeing BBN approach can offer a way of bridging (without necessarily integrating) TK with SK to obtain both qualitative and quantitative assessments about system behaviour (Uusitalo, 2007). Here we demonstrated this by balancing TK with SK in the BBN to assess the cumulative impacts of multiple stressors on a social-ecological system under high uncertainty. The intent of the BBN was to initiate a political power neutral method for knowledge co-production by using multiple modalities including visual aids for data capture, discussion and triangulation during workshops, and by including expert elicitation from local people, Elders, government agents, and natural and social scientists.

In collaboration with scientists, government agencies, and local people, our efforts have built capacity for measuring environmental change, and contributed to developing a potential legacy monitoring tool for adaptation and use by local people to support decision making at various scales. These decisions can take the form of management actions at the community level (e.g., increase monitoring activities and share more TK within the community) as well as the Territorial (e.g., support implementation of the bilateral water agreements) or Federal government (e.g., reduce greenhouse gas emissions) levels. In particular, the nine indices evaluated are most valuable for management, with respect to assessment of change over time in each indicator in relation to cumulative effects. The BBN can now be used as a framework to rank and link such management actions into a system for improving ecosystem health under multiple stressors (e.g., Mantyka-Pringle et al., 2016), while intertwining TK and SK through this process in a more power neutral way.

\subsection{Cumulative effects assessment}

Through a combination of 41 indicators and nine indices that balanced TK and SK, we found that the environmental state of the SRD requires attention. The BBN, which was populated by expert opinion, computed lower probabilities that the SRD is healthy as it used to be when relying on the combined interpretations of traditional observations and scientific data. No single indicator was responsible for any significant change in the model calculations. Experts viewed PAHs and metals in water (SK), and water vitality (TK) as important indicators of water quality. Most important fish and wildlife health indicators were contaminants (SK) and aesthetics (TK). Experts viewed water quality and quantity (SK \& TK) and social change (TK) as important indicators of overall ecosystem health. Out of seven pairs of comparable indicators used in the BBN, TK and SK directly contradicted each other only once (worse physical appearance of water - TK, low turbidity - SK; see Appendix F). For four indicators (fish, birds, mammals, and air pockets/DO) we have TK in a 'worse' state and SK in a 'moderate' state. For one indicator (ice), we have TK in a 'moderate' state and SK in a 'best' state. For one indicator (flow), we have both in a 'worse' state. Although TK and SK can frequently agree with each other in other regions (e.g., Lyver, 2002), our SK indicators were generally ranked as being in moderate condition, whereas TK indicators were ranked as being poor in comparison with the 
past, a common outcome in studies conducted in northern Canada (Parlee et al., 2012; Pearce et al., 2015). It should be remembered that the SK indicators reported here are inherently spatial (i.e., comparing to other locations) while the TK indicators are predominantly temporal (i.e., comparing across time). Together this resulted in higher uncertainty in some of the model calculations as reflected in the similar probabilities of the different responses (i.e., 'no' vs. 'don't know') to the three guiding questions. The different perceptions that were expressed among diverse knowledge holders means that additional data collection and information from the community is needed to reduce the uncertainty in the BBN and to gain clearer confidence in the results.

Our results are consistent with others examining northern Canadian ecosystems (Cash et al., 2000; Dubé et al., 2006; Schindler and Smol, 2006) that rate overall environmental quality as moderate based on SK and poor based on TK. These results, coupled with ours, show that the deep, place-based knowledge held locally leads to an understanding of environmental change that is fundamentally different than that held by western scientists. This may be due to an inability of SK to detect subtle, incremental change over a short time, an altered or unsubstantiated perception of change by local knowledge holders or both (Moller et al., 2004). This disparity does not mean that either knowledge type is invalid, but instead highlights the importance of including both in environmental assessments and management in a balanced way to promote a more holistic understanding of environmental issues.

\subsection{Challenges with blending TK and SK}

The uncertain outputs of the BBN for the three guiding questions mirrors informal and formal discussions with SRD community members and other experts familiar with the region that reveal a range of opinions about water and food safety and ecosystem health. Many believe that while the water, fish and wildlife have changed over time, they are still safe enough to drink and eat, and this is strongly supported by established environmental quality guidelines (e.g., CCME, 1999; Health Canada, 2007). Others have indicated differently, as illustrated in the range of responses from the experts when they took both TK and SK worldviews into context. The discrepancy in these views and the uncertainty in the BBN results is partly epistemological, pertaining to the different ways in which knowledge is derived and used from a specific set of foundational beliefs about the world (Raymond et al., 2010). Because SK is founded upon certain universal truths about the world based on objectivism, those reliant on SK would likely answer 'yes' to the question of whether the water is safe to drink, because it would be based on low levels of chemicals in the water. However, the knowledge derived would be reductionist in nature - reduced to certain universal truths about the world (e.g., the physical properties of chemicals).

Conversely, TK is not derived from universal truths about the world, but rather beliefs and experiences. In this sense TK is more reflexive and agency-driven because it is a product of, for example, different personal stories over time about certain phenomena (e.g., see Stave et al., 2007). If one were to only use TK in answering the same question of whether the water is safe to drink, the output would likely be 'no' because Elders have signposted substantial change in water appearance and vitality through their stories, experiences and multiple observations (Bradford and Bharadwaj, 2015). Thus the knowledge derived would be from different sociocultural contexts, agency-driven (individual stories), and multiple observations, but could not be reduced to any universal truth about the world (e.g. chemical properties of water).

Instead, by balancing SK and TK in our two-eyed seeing BBN, we obtain a higher probability that we 'don't know' whether the water is safe to drink because our BBN allows for a more shared understanding of change in the SRD ecosystem than if we were to exclusively use SK 
or TK. This does not mean that our outputs are correct or unproblematic at the local level because there is no validation outside of the model, and different users may view one form of knowledge as more legitimate than the other in the context of the health of the SRD ecosystem. This makes it difficult to reconcile reductionist SK with a more reflexive TK because the former uses specific universal truths as its knowledge baseline, whilst the latter uses different and multiple beliefs temporally derived from varied socio-cultural local contexts. Yet, our approach contributes to co-adaptive management in social-ecological systems research by offering a way of mitigating or dissolving the potential power geometries that can be initially generated in social learning practices when different epistemological positions are being drawn from SK and TK to solve complex social-ecological problems through co-production methods (Armitage et al., 2011; Berkes, 2009).

\subsection{Limitations}

Our model included only a limited number of variables and input states, which is a limitation of the expert-elicitation approach, especially when weighting and combining factors is required (Camerer and Johnson, 1997). Any conclusions about human health risks in the context of fish, wildlife and water requires more detailed information on consumption rates, age and gender (Health Canada, 2012), the selective discard of rare diseased animals, the relative health benefits of wild-caught vs. store-bought foods (Kuhnlein and Receveur, 1996) and the potential negative impacts of consumption advisories (McAuley and Knopper, 2011) especially as they relate to perception of risk (Slovic, 1987). Additional future interviews within the communities could also focus more specifically on local experiences and perceptions of human health risks related to consumption of traditional foods to provide further detailed information and more concretely address the three guiding questions. Importantly, the establishment of the BBN and the compilation of existing data will allow continual re-visitation of the outputs of the model based on future TK and SK, allowing for an assessment of the change in water and fish safety and ecosystem health over time. We therefore highlight that our modelling approach was intended to be theoretical and preliminary and we emphasize the need for routine updating. Yet, the model is regarded as being a credible and legitimate representation of a complex environment. BBNs can be easily updated as new knowledge about a system becomes available (Marcot et al., 2006), and we recognize the need for more data and additional experts to improve the robustness of model calculations, and to reduce uncertainty.

Due to the nature of the BBN, CPTs of indices and guiding questions were elicited from experts. Some information may, therefore, be biased and based on intuition rather than real data (Martin et al., 2012; O'Hagan et al., 2006). For example, some experts found scenario-based role playing extremely challenging because the best-case scenario, where all parent nodes are in positive states (e.g., high water quantity and high fish and wildlife health), is not currently what is being observed by the SRD community (Bradford and Bharadwaj, 2015). This led to three experts eliciting lower best-case scenario estimates relative to alternative scenarios, a paradoxical result that may have stemmed from a lack of understanding of the elicitation process. Additionally, high levels of confidence expressed by two experts and less knowledge in social change, livelihoods, and food webs as indicated in experts' self-assessments of their expertise may also be other forms of bias (McBride et al., 2012; Moore and Healy, 2008). However, regardless of whether these experts were included or excluded from the model, the BBN showed no major changes in either its output or sensitivity. Such biases were also not consistent across the range of experts or knowledge areas as that would indicate poor elicitation (O'Hagan et al., 2006). In environmental management, there has been a lack of emphasis in understanding peoples' perceptions, including indigenous people (Davidson-Hunt et al., 2013a) and managers (Iftekhar and Pannell, 2015). Agencies should therefore be aware of the influence of biases, but avoid 
the temptation to rely on self-assessment and input from fewer, more highly-specialised experts because diverse 'perceptions' are important and should be communicated to decision-makers (e.g., Martin et al., 2012; Morgan et al., 2001). Instead, experts may require training to convey TK or SK accurately to decision-makers. Thus, we advocate along with others (Raymond et al., 2010) for a shift in science from the development of knowledge integration products to the development of knowledge integration processes enabling multiple views and multiple methods to be considered in relation to an environmental management problem.

\subsection{Policy-relevant insights}

Based on the cumulative information gathered as part of this study, other research (e.g., Pembina Institute, 2016; Wolfe et al., 2007), and historically (e.g., Cash et al., 2000; Dubé et al., 2006; Schindler and Smol, 2006), there is concern for the overall health of the SRD ecosystem. Given the pace of development in upstream watersheds, our case study suggests that management and policy changes, such as fully implementing transboundary water management agreements, should occur to lessen the effects of human and natural activities, including climate change, so that quality and quantity of fish, wildlife and water persist, and indigenous traditional rights continue to be honoured allowing hunting, fishing, gathering and trapping.

Similar to other parts of the world with strong indigenous land tenure such as the Brazilian Amazon (Simmons, 2002) or northern Australia (Jackson et al., 2005), water resources policy needs to be cautious and consider whether risks of development are acceptable given the existing pressures on fish and wildlife, water, the ecosystem, and the effects on livelihoods driven by cumulative impacts and future global change. The successful implementation of adaptive co-management in social-ecological systems that involve multiple stressors are only as effective as the manner in which planning practices are able to bridge TK and SK across distinct ecosystem and jurisdictional territories. NWT is one jurisdiction that has fully embraced the recognition of indigenous values in water management through the NWT Water Stewardship Strategy (GNWT, 2010). Transboundary communication of downstream effects is also necessary for accurate assessment of the potential impacts of upstream development along rivers (Raadgever et al., 2008). The recently signed Alberta-NWT Bilateral Water Management Agreement acknowledges the need to consider traditional knowledge, and also specifically agrees to "identify and implement ways to synthesize and blend traditional and local knowledge, western science and other forms of knowledge in decision-making" (GA and GNWT, 2016).

To enhance political traction between TK and SK, a global policy for indigenous people's cultures and rights should be mainstreamed through all relevant global governance platforms like the United Nations Declaration on the Rights of Indigenous Peoples (Mantyka-Pringle et al., 2015). We are mindful that proximally locating such a policy at the global level may be conceived in some way as detracting from the ethos of TK as a locally and culturally-situated form of knowledge, although globally constructed forms of knowledge often speak to, and are more attractive to, the needs of local policymakers (Turnhout et al., 2016). A global policy would support indigenous participation in environmental agreements and management and answer the calls being made for more TK to influence international global assessments such as the Intergovernmental Panel on Climate Change (IPCC) or the Intergovernmental Platform on Biodiversity and Ecosystem Services (IPBES) (Beck et al., 2014; Ford et al., 2016). More so than the IPCC, the IPBES has gone some way to embracing different knowledges from a variety of audiences working at different scales (Díaz et al., 2015). However, there still remains a push by technical experts to keep assessments more standardized and global in nature (Soberón and Peterson, 2015) rather than attempting to spatially bridge diverse forms of knowledge as a 
means to understand whole system non-linear dynamics of multiple stressors in the

645 environment in the context of social-ecological systems thinking.

646 In the case of provisioning integrated and transdisciplinary approaches, this paper has 647 demonstrated the strengths of bridging TK with SK to support environmental management 648 decision-making. This does not necessarily mean that BBNs are sure-fire ways to bring together 649 the two paradigms respectfully. In some cases (e.g., spiritual practices) it may not be appropriate 650 to attempt any bridging at all, whereas in other cases (e.g., knowledge co-production for 651 conservation), it may be appropriate to go beyond bridging to synthesize the two kinds of 652 knowledge creatively (Johnson et al., 2016). Each bridging effort will be unique and will no 653 doubt take much hard work from all the partners involved. Still, we believe that the balancing 654 of TK and SK can be achieved in other monitoring and research programs worldwide for 655 improved conservation and resource management that transformatively draws from the wider 656 normative framework of adaptive co-management in social-ecological systems.

\section{AUTHOR'S CONTRIBUTION}

658 The study was devised by all authors. The BBN was developed and implemented by C.M-P. 659 and T.J. Data was collected by the SRDP, T.J., L.Bh., G.S., K-E.L., L.D., and P.J. C.M-P. wrote 660 the manuscript; all authors substantially edited the manuscript as listed in order of contribution.

\section{ACKNOWLEDGEMENTS}

662 We thank the people of Fort Resolution Métis Council, Northwest Territories Métis Nation, 663 Deninu K'ue First Nation, Hamlet of Fort Resolution, Town of Fort Smith, Fort Smith Métis 664 Council, Smith's Landing First Nation, and Salt River First Nation for their willingness to 665 participate in the research. Funding for this project was provided by the Canadian Water 666 Network and the Government of the Northwest Territories (GNWT) Environment and Natural 667 Resources. Special thanks to the experts that attended the expert elicitation workshops and 668 GNWT Municipal and Community Affairs for their support. 
670

671

672

673

674

675

676

677

678

679

680

681

682

683

684

685

686

687

688

689

690

691

692

693

694

695

696

697

698

699

700

701

702

703

704

705

706

AANDC and GNWT-ENR. (2012) Our water, our life: building partnerships to assess the health of the Slave River and Slave River Delta. Summary Report for the Community Workshop Convened in the Fort Smith, NWT on 1-2 March 2011. Aboriginal Affairs and Northern Development Canada (AANDC) and Government of the Northwest Territories Department of Environment and Natural Resources (GNWT-ENR), Yellowknife, NWT, Canada.

Armitage, D., Berkes, F., Dale, A., Kocho-Schellenberg, E., Patton, E. (2011) Comanagement and the co-production of knowledge: Learning to adapt in Canada's Arctic. Global Environmental Change 21, 995-1004.

Ball, J., Janyst, P. (2008) Enacting research ethics in partnerships with indigenous communities in Canada: "Do it in a good way". Journal of Empirical Research on Human Research Ethics 3, 33-51.

Ban, S.S., Pressey, R.L., Graham, N.A.J. (2014) Assessing interactions of multiple stressors when data are limited: A Bayesian belief network applied to coral reefs. Global Environmental Change 27, 64-72.

Barber, M., Jackson, S. (2015) 'Knowledge Making': Issues in Modelling Local and Indigenous Ecological Knowledge. Human Ecology 43, 119-130.

Bartlett, C., Marshall, M., Marshall, A. (2012) Two-Eyed Seeing and other lessons learned within a co-learning journey of bringing together indigenous and mainstream knowledges and ways of knowing. Journal of Environmental Studies and Sciences 2, 331-340.

Beck, S. (2011) Moving beyond the linear model of expertise? IPCC and the test of adaptation. Regional Environmental Change 11, 297-306.

Beck, S., Borie, M., Chilvers, J., Esguerra, A., Heubach, K., Hulme, M., Lidskog, R., Lövbrand, E., Marquard, E., Miller, C. (2014) Towards a reflexive turn in the governance of global environmental expertise. The cases of the IPCC and the IPBES. GAIA-Ecological Perspectives for Science and Society 23, 80-87.

Bender, M., Floeter, S., Hanazaki, N. (2013) Do traditional fishers recognise reef fish species declines? Shifting environmental baselines in Eastern Brazil. Fisheries Management and Ecology 20, 58-67.

Berkes, F. (2009) Evolution of co-management: role of knowledge generation, bridging organizations and social learning. Journal of Environmental Management 90, 1692-1702.

Berkes, F. (2012) Sacred ecology. Routledge.

Berkes, F., Colding, J., Folke, C. (2000) Rediscovery of traditional ecological knowledge as adaptive management. Ecological Applications 10, 1251-1262.

Bohensky, E.L., Butler, J.R., Davies, J. (2013) Integrating indigenous ecological knowledge and science in natural resource management: perspectives from Australia. Ecology and Society 18, 20. 
Bradford, L.E., Bharadwaj, L.A. (2015) Whiteboard animation for knowledge mobilization: a test case from the Slave River and Delta, Canada. International journal of circumpolar health 74.

Briggs, J. (2013) Indigenous knowledge: A false dawn for development theory and practice? Progress in Development Studies 13, 231-243.

Brock, B., Wolfe, B., Edwards, T. (2008) Spatial and temporal perspectives on spring breakup flooding in the Slave River Delta, NWT. Hydrological Processes 22, 4058-4072.

Brook, R.K., McLachlan, S.M. (2008) Trends and prospects for local knowledge in ecological and conservation research and monitoring. Biodiversity and Conservation 17, 3501-3512.

Cain, J. (2001) Planning improvements in natural resources management: Guidelines for using Bayesian networks to support the planning and management of development programmes in the water sector and beyond. Centre for Ecology and Hydrology, Crowmarsh Gifford, Wallingford, UK.

Camerer, C.F., Johnson, E.J., (1997) The process-performance paradox in expert judgment: How can experts know so much and predict so badly?, in: Goldstein, W., Hogarth, R. (Eds.), Research on judgment and decision making: Currents, connections and controversies. Cambridge University Press, Cambridge, pp. 342-364.

Cash, K.J., Gibbons, W.N., Munkittrick, K.R., Brown, S.B., Carey, J. (2000) Fish health in the Peace, Athabasca and Slave river systems. Journal of Aquatic Ecosystem Stress and Recovery 8, 77-86.

CCME. (1999) Canadian Environmental Quality Guidelines (and updates). Canadian Council of Ministers of the Environment (CCME), Winnipeg, http://ceqg-rcqe.ccme.ca (viewed November 1, 2014).

Chaffin, B.C., Gosnell, H., Cosens, B.A. (2014) A decade of adaptive governance scholarship: synthesis and future directions. Ecology and Society 19, 56.

Davidson-Hunt, I.J., Idrobo, C.J., Pengelly, R.D., Sylvester, O. (2013) Anishinaabe Adaptation to Environmental Change in Northwestern Ontario: a Case Study in Knowledge Coproduction for Nontimber Forest Products. Ecology and Society 18, 44.

Díaz, S., Demissew, S., Joly, C., Lonsdale, W.M., Larigauderie, A. (2015) A Rosetta Stone for nature's benefits to people. PLoS Biology 13, e1002040.

Dubé, M., Johnson, B., Dunn, G., Culp, J., Cash, K., Munkittrick, K., Wong, I., Hedley, K., Booty, W., Lam, D. (2006) Development of a new approach to cumulative effects assessment: a northern river ecosystem example. Environmental Monitoring and Assessment 113, 87-115.

English, M.C., Hill, R.B., Stone, M.A., Ormson, R. (1997) Geomorphological and botanical change on the outer Slave River Delta, NWT, before and after impoundment of the Peace River. Hydrological Processes 11, 1707-1724.

Ferreira, J., Aragão, L.E.O.C., Barlow, J., Barreto, P., Berenguer, E., Bustamante, M., Gardner, T.A., Lees, A.C., Lima, A., Louzada, J., Pardini, R., Parry, L., Peres, C.A., Pompeu, 
P.S., Tabarelli, M., Zuanon, J. (2014) Brazil's environmental leadership at risk. Science 346, 706-707.

Fischer, F. (2000) Citizens, experts, and the environment: The politics of local knowledge. Duke University Press.

Folke, C., Hahn, T., Olsson, P., Norberg, J. (2005) Adaptive governance of social-ecological systems. Annual Review of Environment and Resources 30, 441-473.

Ford, J.D., Cameron, L., Rubis, J., Maillet, M., Nakashima, D., Willox, A.C., Pearce, T. (2016) Including indigenous knowledge and experience in IPCC assessment reports. Nature Climate Change 6, 349-353.

GA and GNWT. (2016). Mackenzie River Basin Bilateral Water Management Agreement between the Government of Alberta and the Government of the Northwest Territories. Government of Alberta (GA) and Government of the Northwest Territories (GNWT), Edmonton, Alberta, and Yellowknife, Northwest Territories, Canada.

Gerhardinger, L.C., Godoy, E.A., Jones, P.J. (2009) Local ecological knowledge and the management of marine protected areas in Brazil. Ocean \& Coastal Management 52, 154-165.

GNWT, (2010). Northern voices, northern waters: NWT water stewardship strategy. Environment and Natural Resources, Yellowknife, Government of the Northwest Territories (GNWT), Canada.

Halseth, R., (2015) The nutritional health of the First nations and Metis of the Northwest Territories: A review of current knowledge and gaps. National Collaborating Centre for Aboriginal Health, Prince George, BC http://www.nccahccnsa.ca/34/publications.nccah?publication=141 (viewed November 1, 2014).

Health Canada. (2007) Human health risk assessment of mercury in fish and health benefits of fish consumption. Government of Canada, Ottawa, http://www.hc-sc.gc.ca/fnan/pubs/mercur/merc fish poisson-eng.php (viewed November 1, 2014).

Health Canada. (2012) Federal Contaminated Site Risk Assessment in Canada, Part I: Guidance on Human Health Preliminary Quantitative Risk Assessment (PQRA), Version 2.0. Government of Canada, Ottawa, http://www.hc-sc.gc.ca/ewh-semt/pubs/contamsite/partpartie i/index-eng.php (viewed November 1, 2014).

Hill, R., Grant, C., George, M., Robinson, C.J., Jackson, S., Abel, N. (2012) A typology of indigenous engagement in Australian environmental management: implications for knowledge integration and social-ecological system sustainability. Ecology and Society 17, 117.

Houde, N. (2007) The six faces of traditional ecological knowledge: challenges and opportunities for Canadian co-management arrangements. Ecology and Society 12, 34.

Huntington, H.P. (2000) Using traditional ecological knowledge in science: methods and applications. Ecological Applications 10, 1270-1274.

Iftekhar, M.S., Pannell, D.J. (2015) 'Biases' in adaptive natural resource management. Conservation Letters 8, 388-396. 
Jackson, S., Storrs, M., Morrison, J. (2005) Recognition of Aboriginal rights, interests and values in river research and management: perspectives from northern Australia. Ecological Management \& Restoration 6, 105-110.

Jensen, F.V. (1996) An introduction to Bayesian networks. UCL press London.

Johnson, J.T., Howitt, R., Cajete, G., Berkes, F., Louis, R.P., Kliskey, A. (2016) Weaving Indigenous and sustainability sciences to diversify our methods. Sustainability Science 11, 111 .

Johnson, S., Marker, L., Mengersen, K., Gordon, C.H., Melzheimer, J., Schmidt-Küntzel, A., Nghikembua, M., Fabiano, E., Henghali, J., Wachter, B. (2013) Modeling the viability of the free-ranging cheetah population in Namibia: an object-oriented Bayesian network approach. Ecosphere 4, 1-19.

Kjaerulff, U.B., Madsen, A.L. (2008) Bayesian networks and influence diagrams. Springer Science+ Business Media 200, 114.

Kuhnert, P.M., Martin, T.G., Griffiths, S.P. (2010) A guide to eliciting and using expert knowledge in Bayesian ecological models. Ecology Letters 13, 900-914.

Kuhnlein, H.V., Receveur, O. (1996) Dietary change and traditional food systems of indigenous peoples. Annual Review of Nutrition 16, 417-442.

Lemos, M.C. (2015) Usable climate knowledge for adaptive and co-managed water governance. Current Opinion in Environmental Sustainability 12, 48-52.

Leonard, S., Parsons, M., Olawsky, K., Kofod, F. (2013) The role of culture and traditional knowledge in climate change adaptation: Insights from East Kimberley, Australia. Global Environmental Change 23, 623-632.

Lyver, P. (2002) Use of Traditional Knowledge by Rakiura Maori to Guide Sooty Shearwater Harvests. Wildlife Society Bulletin (1973-2006) 30, 29-40.

Mantyka-Pringle, C., Westman, C., Kythreotis, A., Schindler, D. (2015) Honouring indigenous treaty rights for climate justice. Nature Climate Change 5, 798-801.

Mantyka-Pringle, C.S., Martin, T.G., Moffatt, D.B., Linke, S., Rhodes, J.R. (2014) Understanding and predicting the combined effects of climate change and land-use change on freshwater macroinvertebrates and fish. Journal of Applied Ecology 51, 572-581.

Mantyka-Pringle, C.S., Martin, T.G., Moffatt, D.B., Udy, J., Olley, J., Saxton, N., Sheldon, F., Bunn, S.E., Rhodes, J.R. (2016) Prioritizing management actions for the conservation of freshwater biodiversity under changing climate and land-cover. Biological Conservation 197, 80-89.

Marcot, B.G., Steventon, J.D., Sutherland, G.D., McCann, R.K. (2006) Guidelines for developing and updating Bayesian belief networks applied to ecological modeling and conservation. Canadian Journal of Forest Research 36, 3063-3074. 
Martin, T.G., Burgman, M.A., Fidler, F., Kuhnert, P.M., LOW-CHOY, S., McBride, M., Mengersen, K. (2012) Eliciting expert knowledge in conservation science. Conservation Biology 26, 29-38.

Martin, T.G., Murphy, H., Liedloff, A., Thomas, C., Chadès, I., Cook, G., Fensham, R., McIvor, J., van Klinken, R.D. (2015) Buffel grass and climate change: a framework for projecting invasive species distributions when data are scarce. Biological Invasions 17, 1-14.

McAuley, C., Knopper, L.D. (2011) Impacts of traditional food consumption advisories: Compliance, changes in diet and loss of confidence in traditional foods. Environmental Health 10,55 .

McBride, M.F., Fidler, F., Burgman, M.A. (2012) Evaluating the accuracy and calibration of expert predictions under uncertainty: predicting the outcomes of ecological research. Diversity and Distributions 18, 782-794.

McGregor, S., Lawson, V., Christophersen, P., Kennett, R., Boyden, J., Bayliss, P., Liedloff, A., McKaige, B., Andersen, A.N. (2010) Indigenous wetland burning: conserving natural and cultural resources in Australia's World Heritage-listed Kakadu National Park. Human Ecology 38, 721-729.

Mistry, J., Berardi, A. (2016) Bridging indigenous and scientific knowledge. Science 352, 1274-1275.

Moller, H., Berkes, F., Lyver, P.O.B., Kislalioglu, M. (2004) Combining science and traditional ecological knowledge: monitoring populations for co-management. Ecology and Society $9,2$.

Moore, D.A., Healy, P.J. (2008) The trouble with overconfidence. Psychological Review 115, 502-517.

Morgan, M.G., Pitelka, L.F., Shevliakova, E. (2001) Elicitation of Expert Judgments of Climate Change Impacts on Forest Ecosystems. Climatic Change 49, 279-307.

Nadasdy, P. (1999) The politics of TEK: Power and the" integration" of knowledge. Arctic Anthropology, 1-18.

Norsys Software Corporation. (2008) Netica 4.08. Norsys Software, Vancouver, BC, Canada.

NWTBS. (2014). Households Eating Meat or Fish from Hunting or Fishing in 2013 and Amount by Community. Northwest Territories Bureau of Statistics (NWTBS), Government of the Northwest Territories, Canada, http://www.statsnwt.ca/Traditional\%20Activities/ (viewed July 11, 2016).

Nyberg, J.B., Marcot, B.G., Sulyma, R. (2006) Using Bayesian belief networks in adaptive management. Canadian Journal of Forest Research 36, 3104-3116.

O'Hagan, A., Buck, C.E., Daneshkhah, A., Eiser, J.R., Garthwaite, P.H., Jenkinson, D.J., Oakley, J.E., Rakow, T. (2006) Uncertain judgements: eliciting experts' probabilities. John Wiley \& Sons. 
Obidzinski, K., Andriani, R., Komarudin, H., Andrianto, A. (2012) Environmental and Social Impacts of Oil Palm Plantations and the Implications for Biofuel Production in Indonesia. Ecology and Society 17, 25.

Olsson, P., Folke, C., Berkes, F. (2004) Adaptive comanagement for building resilience in social-ecological systems. Environmental Management 34, 75-90.

Parlee, B.L., Geertsema, K., Willier, A. (2012) Social-ecological thresholds in a changing boreal landscape: insights from Cree knowledge of the Lesser Slave Lake region of Alberta, Canada. Ecology and Society 17, 20.

Pembina Institute. (2016) Vulnerability Assessment of the Slave River and Delta. Summary report for the Community Workshop convened in Fort Smith, January 24-26, 2012. Pembina Instatute, Edmonton, 546 pp. http://www.nwtwaterstewardship.ca/srdp

Pearce, T., Ford, J., Willox, A.C., Smit, B. (2015) Inuit Traditional Ecological Knowledge (TEK), Subsistence Hunting and Adaptation to Climate Change in the Canadian Arctic. Arctic $68,233-245$.

Pielke, R.A. (2007) The honest broker: making sense of science in policy and politics. Cambridge Univ Press.

Pinkerton, E., (1998) Integrated management of a temperate montane forest ecosystem through wholistic forestry: a British Columbia example., in: Berkes, F., Folke, C. (Eds.), Linking social and ecological systems: management practices and social mechanisms for building resilience. Cambridge University Press, Cambridge, UK, pp. 363-389.

Raadgever, G., Mostert, E., Kranz, N., Interwies, E., Timmerman, J.G. (2008) Assessing management regimes in transboundary river basins: do they support adaptive management? Ecology and Society 13, 14.

Raymond, C.M., Fazey, I., Reed, M.S., Stringer, L.C., Robinson, G.M., Evely, A.C. (2010) Integrating local and scientific knowledge for environmental management. Journal of Environmental Management 91, 1766-1777.

Reid, W., Berkes, F., Wilbanks, T., Capistrano, D. (2006) Bridging scales and knowledge systems: linking global science and local knowledge in assessments. Millennium Ecosystem Assessment and Island Press, Washington, DC.

Schindler, D.W. (2001) The cumulative effects of climate warming and other human stresses on Canadian freshwaters in the new millennium. Canadian Journal of Fisheries and Aquatic Sciences 58, 18-29.

Schindler, D.W., Smol, J.P. (2006) Cumulative Effects of Climate Warming and Other Human Activities on Freshwaters of Arctic and Subarctic North America. AMBIO: A Journal of the Human Environment 35, 160-168.

Schnarch, B. (2004) Ownership, control, access, and possession (OCAP) or selfdetermination applied to research. Journal of Aboriginal Health 1, 80-95.

Schwalb, A.N., Alexander, A.C., Paul, A.J., Cottenie, K., Rasmussen, J.B. (2014) Changes in migratory fish communities and their health, hydrology, and water chemistry in rivers of the 
Athabasca oil sands region: a review of historical and current data. Environmental Reviews $23,1-18$.

Segner, H., Schmitt-Jansen, M., Sabater, S. (2014) Assessing the impact of multiple stressors on aquatic biota: the receptor's side matters. Environmental Science \& Technology 48, 76907696.

Simmons, C.S. (2002) The local articulation of policy conflict: Land use, environment, and Amerindian rights in eastern Amazonia. The Professional Geographer 54, 241-258.

Slovic, P. (1987) Perception of risk. Science 236, 280-285.

Soberón, J., Peterson, A.T. (2015) Biodiversity governance: a tower of Babel of scales and cultures. PLoS Biology 13, e1002108.

Stave, J., Oba, G., Nordal, I., Stenseth, N.C. (2007) Traditional ecological knowledge of a riverine forest in Turkana, Kenya: implications for research and management. Biodiversity and Conservation 16, 1471-1489.

Stringer, L.C., Dougill, A.J., Fraser, E., Hubacek, K., Prell, C., Reed, M.S. (2006) Unpacking "participation" in the adaptive management of social-ecological systems: a critical review. Ecology and Society 11, 39.

Sutherland, W.J., Gardner, T.A., Haider, L.J., Dicks, L.V. (2014) How can local and traditional knowledge be effectively incorporated into international assessments? Oryx 48, 1 2.

Turnhout, E., Dewulf, A., Hulme, M. (2016) What does policy-relevant global environmental knowledge do? The cases of climate and biodiversity. Current Opinion in Environmental Sustainability $18,65-72$.

Uusitalo, L. (2007) Advantages and challenges of Bayesian networks in environmental modelling. Ecological Modelling 203, 312-318.

Whyte, K.P., Brewer II, J.P., Johnson, J.T. (2015) Weaving Indigenous science, protocols and sustainability science. Sustainability Science 11, 25-32.

Wiegmann, D.A. (2005) Developing a methodology for eliciting subjective probability estimates during expert evaluations of safety interventions: Application for bayesian belief networks. NASA Langley Research Center, Hampton, VA, 9 pp. http://ntrs.nasa.gov/search.jsp?R=20050238445

Wolfe, B.B., Armitage, D., Wesche, S., Brock, B.E., Sokal, M.A., Clogg-Wright, K.P., Mongeon, C.L., Adam, M.E., Hall, R.I., Edwards, T.W. (2007) From isotopes to TK interviews: towards interdisciplinary research in Fort Resolution and the Slave River Delta, Northwest Territories. Arctic 60, 75-87. 


\section{SUPPLEMENTARY MATERIAL}

931 Additional supporting information may be found in the online version of this article at the publisher's web-site.

\section{Appendix A.}

933 Table A1. Description of the indicators used in the Bayesian Belief Network and the states of these variables. *Indicators that are based on Traditional Knowledge.

\begin{tabular}{|c|c|c|c|c|c|}
\hline Node & Description; Categorization methodology & \multicolumn{4}{|l|}{ States } \\
\hline Turbidity & $\begin{array}{l}\text { The amount of cloudiness in the water. The thresholds were derived } \\
\text { from Fort Smith Slave river site, from data collected during 1982- } \\
2010 \text { open water (May-October) by the Government of the Northwest } \\
\text { Territories (GNWT). }\end{array}$ & \multicolumn{4}{|c|}{$\begin{array}{l}\text { Low }<220 \text { NTU } \\
\text { Medium 220-600 NTU } \\
\text { High }>600 \text { NTU }\end{array}$} \\
\hline PAHs & $\begin{array}{l}\text { These are the polycyclic aromatic compounds, chemicals (some } \\
\text { natural, some anthropogenic) that can cause cancer. The thresholds } \\
\text { were derived from Fort Smith Slave river site, from data collected } \\
\text { during 1982-2010 open water (May-October) by the GNWT. }\end{array}$ & \multicolumn{4}{|c|}{$\begin{array}{l}\text { Low }<100 \mathrm{ng} / \mathrm{L} \\
\text { Medium } 100-400 \mathrm{ng} / \mathrm{L} \\
\text { High }>400 \mathrm{ng} / \mathrm{L}\end{array}$} \\
\hline Dissolved Phosphorus & $\begin{array}{l}\text { Inorganic and organic phosphorus that remains in water after it has } \\
\text { been filtered to remove particulate matter. The thresholds were } \\
\text { derived from Fort Smith Slave river site, from data collected during } \\
\text { 1982-2010 open water (May-October) by the GNWT. }\end{array}$ & \multicolumn{4}{|c|}{$\begin{array}{l}\text { Low }<0.35 \mathrm{mg} / \mathrm{L} \\
\text { Medium } 0.35-0.65 \mathrm{mg} / \mathrm{L} \\
\text { High }>0.65 \mathrm{mg} / \mathrm{L}\end{array}$} \\
\hline Metals (Dissolved and Total) & $\begin{array}{l}\text { A combination of elements flagged in Kelly et al. (2010). Thresholds } \\
\text { are based on the Canadian Water Quality Guidelines (CCME, 1999) } \\
\text { and derived from Fort Smith Slave river site, from data collected } \\
\text { during } 1982-2010 \text { open water (May-October) by the GNWT. All units } \\
\text { of measurement are in } \mu \mathrm{g} / \mathrm{L} \text {. }\end{array}$ & $\begin{array}{l}\text { Arsenic } \\
\text { Cadmium } \\
\text { Chromium } \\
\text { Copper } \\
\text { Iron } \\
\text { Lead } \\
\text { Mercury } \\
\text { Nickel } \\
\text { Zinc }\end{array}$ & $\begin{array}{c}\text { Low norm } \\
\quad<5 \\
\quad<1 \\
<30 \\
<20 \\
<17100 \\
\quad<10 \\
<0.2 \\
<30 \\
<75\end{array}$ & $\begin{array}{c}\text { high normal } \\
5.01-15 \\
1.01-10 \\
30.01-90 \\
20.01-45 \\
17100.01-25200 \\
10.01-22 \\
0.22-0.39 \\
30.01-60 \\
75.01-160\end{array}$ & $\begin{array}{l}\text { investigate } \\
\qquad 15 \\
>10 \\
>90 \\
>45 \\
>25200 \\
>22 \\
>0.4 \\
>60 \\
>160\end{array}$ \\
\hline
\end{tabular}




\begin{tabular}{|c|c|c|}
\hline *Water Vitality & $\begin{array}{l}\text { How the water spiritually makes someone feel (sad = not moving with } \\
\text { as much joy)? Many of these traditional knowledge indicators } \\
\text { represent a measure of cultural health (Tipa and Teirney, 2003). }\end{array}$ & $\begin{array}{l}\text { Dead = Indigenous users no longer feel a spiritual connection to } \\
\text { the water } \\
\text { Alive = Indigenous users feel alive when they think about the } \\
\text { water } \\
\text { Full of Spirit = Indigenous users feel alive and full of spirit in the } \\
\text { presence of the water }\end{array}$ \\
\hline *Physical Appearance & Has the water movement or visibility changed over time? & $\begin{array}{l}\text { Worse }=\text { water looks worse now than in the past } \\
\text { Same = water looks the same now as in the past } \\
\text { Better = water looks better now than in the past }\end{array}$ \\
\hline *Fish Aesthetics & What proportion of fish have deformities and/or lesions? & $\begin{array}{l}\text { Worse = the fish look worse now than in the past } \\
\text { Same = the fish look the same now as they did in the past } \\
\text { Better = the fish look better than in the past }\end{array}$ \\
\hline *Fish Usage & $\begin{array}{l}\text { Has the number of fish caught changed in the Slave River and Delta } \\
\text { (SRD)? Variable is correlated with number of species and fish } \\
\text { distribution. }\end{array}$ & $\begin{array}{l}\text { Less }=\text { I use less fish now than I did in the past } \\
\text { Same }=\text { I use the same amount of fish now than I did in the past } \\
\text { More = I use more fish now than I did in the past }\end{array}$ \\
\hline Fish External Anomalies & $\begin{array}{l}\text { The number of external anomalies (cysts, tumors, lesions and } \\
\text { malformations - e.g., shortening of fins) on the fish relative to all fish } \\
\text { examined - combining data from all species. Thresholds are based on } \\
\text { Brown et al. (1973), Karr (1991), Munkittrick et al. (1992). }\end{array}$ & $\begin{array}{l}\text { Low }=<1 \% \\
\text { Moderate }=1-5 \% \\
\text { High }=>5 \%\end{array}$ \\
\hline Fish Internal Anomalies & $\begin{array}{l}\text { The number of internal anomalies (cysts, tumors, lesions and } \\
\text { malformations - e.g. shortening of liver) in the internal organs of fish } \\
\text { relative to all fish examined - combining data from all species. } \\
\text { Thresholds based on Brown et al. (1973), Karr (1991), Baumann et al. } \\
\text { (1991). }\end{array}$ & $\begin{array}{l}\text { Low }=<1 \% \\
\text { Moderate }=1-5 \% \\
\text { High }=>5 \%\end{array}$ \\
\hline Fish Bile PAHs & $\begin{array}{l}\text { The mean concentration of polycyclic aromatic hydrocarbons in fish } \\
\text { bile based on synchronous fluorescence scanning. Averaged across } \\
\text { five fish species (Burbot, Goldeye, Jackfish, Walleye, Whitefish). } \\
\text { Thresholds are based on van den Heuvel et al. (1999), Ohiozebau et al. } \\
\text { (2015). }\end{array}$ & $\begin{array}{l}\text { Low }=<2000 \mathrm{ng} / \mathrm{mL} \\
\text { Moderate }=2000-5000 \mathrm{ng} / \mathrm{mL} \\
\text { High }=>5000 \mathrm{ng} / \mathrm{mL}\end{array}$ \\
\hline
\end{tabular}


Mercury in Fish

Muskrat Mercury

Moose Stress

*Mammal Usage

*Mammal Aesthetics

*Flood Extent

*Water Flow

Water Depth
The mean concentration of mercury in fish tissue. Averaged across species - Northern pike and Walleye. Health Canada guidelines for infrequent and frequent consumption (Health Canada, 2007).

Mercury in muskrat tissues. Thresholds are based on Halbrook et al. (1993), McLachlan (2014), Sheffy and St. Amant (1982).

Stress hormone concentrations in hunted moose. Thresholds are based on concentrations in related species subjected to various stressors (Ashley et al., 2011; Macbeth et al., 2010).

Has the number of species changed over time? Variable is correlated with number of mammals and distribution of species.

What proportion of mammals have disease?

Are there changes to the annual floods (is the environment being renewed)?

Are there changes to the water flow (movement, depth, day to day changes)?

Bathymetry of the river and delta channels during summer. Thresholds are based on health and safety estimates as per expert knowledge (coauthor K. Lindenschmidt) using the maximum and minimum range of average water depth measured during the bathymetry survey.
Low $=<0.2$ ppm wet weight

Moderate $=0.2$ to $0.5 \mathrm{ppm}$ wet weight

High $=>0.5 \mathrm{ppm}$ wet weight

Low $<0.05$ ppm dry weight

Moderate 0.05 to $0.2 \mathrm{ppm}$ dry weight

High $>0.2$ ppm dry weight

Low $<1 \mathrm{pg} / \mathrm{mg}$

Moderate $=1-5 \mathrm{pg} / \mathrm{mg}$

High $=>5 \mathrm{pg} / \mathrm{mg}$

Less $=$ I use less mammals now than I did in the past

Same $=$ I use the same amount of mammals now as I did in the past

More $=\mathrm{I}$ use more mammals now than I did in the past

Worse $=$ the mammals look worse now than they did in the past Same $=$ the mammals look the same now as they did in the past Better $=$ the mammals look better now than they did in the past

Less $=$ the floods cover less area/land now than they did in the past

Same $=$ the floods cover the same amount of area/land now than they did in the past

More $=$ the floods cover more area/land now than they did in the past

Less $=$ there is less water flow now than there was in the past

Same $=$ there is the same water flow now than there was in the past

More $=$ there is more water flow now than there was in the past

Shallow $(<1 \mathrm{~m})$

Medium (1 -2 m)

Deep $(>2 \mathrm{~m})$ 
Flow Regime

Seasonal dynamic of river flow during winter based on daily average

flow along the Slave River at Fitzgerald gauge station. Thresholds

based on expert knowledge (co-author K. Lindenschmidt)

*Plant Usage

Has the vegetation become more unfamiliar?

Has there been more harvesting of available vegetation food sources? Species lost that were used for consumption or medicine in the past? Has there been changes to locations where plants/roots can be

harvested?

\section{Invertebrate Density}

Invertebrate Taxa Richness

Mean number of macroinvertebrates per $\mathrm{m}^{2}$ of Hester-Dendy samplers from three sites (two in the delta, one at Fort Smith). Thresholds calculated using $5^{\text {th }}$ and $95^{\text {th }}$ percentile values.

Mean number of macroinvertebrate taxa at three sites (two in the delta one at Fort Smith). Thresholds calculated using $5^{\text {th }}$ and $95^{\text {th }}$ percentile values.

Shannon Wiener Index

A diversity index that reflects how many different types of species there are at a site and the evenness of their relative numbers.

Thresholds calculated using $5^{\text {th }}$ and $95^{\text {th }}$ percentile values.

Maximum daily counts of "ducks" from hourly time-lapse photos at three delta wetlands. Thresholds based on expert knowledge relative to a well-studied reference site (co-author T. Jardine).
Lower discharge $(<3000 \mathrm{cms})$ (forms more black-ice covers)

Medium discharge $(3000-6000 \mathrm{cms})$ forms more consolidated

ice covers;

High discharge ( $>6000 \mathrm{cms})$ ice-out conditions; $6000 \mathrm{cms}$ is approximate $\mathrm{T}=6.5$ year breakup flood

Less $=$ I use less traditional plants now than I did in the past

Same $=$ I use the same amount of traditional plants now as I did in the past

More $=$ I use more traditional plants now than I did in the past

Less $=$ there are less unfamiliar/invasive plants now than in the past

Same $=$ there are the same amount of unfamiliar/invasive plants now than in the past

More $=$ there are more unfamiliar/invasive plants now than in the past

Low $<386$ macroinvertebrates $/ \mathrm{m}^{2}$

Medium 386 to 1388 macroinvertebrates $/ \mathrm{m}^{2}$

High $>1388$ macroinvertebrates $/ \mathrm{m}^{2}$

Low $<6.2$ taxa

Medium 6.2 to 8.6 taxa

High $>8.6$ taxa

Low $<1.49$

Medium 1.49 to 2.19

High $>2.19$

Low $=<10$

Moderate $=10$ to 50

High $=>50$ 
*Bird Usage

*Bird Aesthetics

*Cultural Changes

*Storytelling

*Animal Ethics

Fur-bearer Abundance

*Ecotourism
Has there been changes to the number of birds present? Variable is correlated with number of species and bird distribution.

Has there been changes to the bird health overall?

More use of technology to aid harvesting and trapping?

Changes in symbolic use of animals in story-telling and culture?

Have unethical behaviours toward large animals been observed (not sharing, boasting, wastage, over-harvesting)?

Number of trapped muskrats per year within trapping block Thresholds based on long-term records held by the GNWT and compared to other river deltas in Saskatchewan.

Has tourism changed?
Less $=$ I harvest and use less birds now than I did in the past

Same $=$ I harvest and use the same amount of birds now than I

did in the past

More $=\mathrm{I}$ harvest and use more birds now than I did in the past

Worse $=$ the birds look worse now than they did in the past Same $=$ the birds look the same now as they did in the past Better $=$ the birds look better now than they did in the past

More $=$ our culture is now shifting away from what it was in the past because of changes to the delta (less trapping, less fishing, etc.)

Same $=$ our culture is not changing now

Less $=$ our culture is shifting more now to what it was like in the past

Infrequent $=$ we use storytelling infrequently now to share our beliefs than in the past because of changes to the delta.

Frequent $=$ we use storytelling frequently now to share our beliefs than in the past

Poor $=$ people have poorer ethics/respect towards animals now than in the past?

Same $=$ people have the same ethics/respect towards animals now than in the past

Better $=$ people have better ethics/respect towards animals now than in the past

Low $=<500$

Moderate $=500$ to 5000

High $=>5000$

Less $=$ there is less ecotourism now than in the past because of changes in the delta

Same $=$ there is the same amount of ecotourism now than in the past

More $=$ there is more ecotourism now than in the past 
*Adaptation

Ice Thickness

DO under ice

*Length of Ice Period
Fear of not being able to adapt.

The thickness of ice during peak winter months. Thresholds based on literature (GoA, 2013).

Mean magnitude of dissolved oxygen and dissolved oxygen saturation underneath of the ice cover. Air can detrain or degas from

supersaturated water to form air bubbles and pockets under the ice

surface. Hence, less saturation means less air pocket formation.

Thresholds based on expert opinion (co-author K. Lindenschmidt)

Records of ice in and ice out dates.
Less = we rely less on harvesting from the delta now than in the past because of changes to the delta

Same $=$ we harvest the same from the delta now as we did in the past

More $=$ we rely on harvesting more from the delta now than in the past

Less $=$ I rely less on traveling in the delta now than in the past to maintain my livelihood

Same $=$ I travel the same amount in the delta than in the past

More $=$ I rely more on traveling in the delta now than in the past

Less $=\mathrm{I}$ adapt my livelihood less now than I did in the past because of changes in the river and delta

Same $=$ I use the same livelihoods now as I did in the past

More $=\mathrm{I}$ adapt my livelihood more now than I did in the past

Thin $(<15 \mathrm{~cm})$

Medium (15 - $40 \mathrm{~cm})$ Snowmobile travel possible

Thick $(>40 \mathrm{~cm})$ Small truck travel possible

Unsaturated $(<95 \%)$ - most positive

Saturated $(95-105 \%)$

Supersaturated (>105\%) - most negative

Short $(<5.5$ months) - ice freeze up happens later (December) and thaws sooner (i.e., March) than in the past

Medium (5.5 - 6.5 months) - ice freeze up happens the same as in the past (October - April/May)

Long ( $>6.5$ months) - ice freeze up happens sooner and lasts longer than in the past (September/October - May) 
*Ice Significance

Represents the spiritual connection with people when they are free

from winter.

*Air Pocket Density
Less $=$ the ice and floods mean less to me personally than in the

past

Same $=$ the ice and floods mean the same to me personally as they did in the past

More $=$ the ice and floods mean more to me personally than they did in the past

Less $=$ there are few air pockets in the ice now than in the past Same $=$ there are an average number of air pockets in the ice now than in the past

More $=$ there are more air pockets in the ice now than in the past 


\section{Turbidity}

Polycyclic aromatic compounds

\section{Dissolved phosphorus}

\section{Metals}

Fish external anomalies
EXO multiparameter water quality Sondes and YSI 6600 Sondes were used to sample the surrounding water at three sites during the open water season (May-October) by the Government of the Northwest Territories (GNWT) Environment and Natural Resources (ENR). Two of the sites were on the Slave River, one at the Rapids of the Drowned at Fort Smith and another at Big Eddy near the town of Fort Resolution. The third site was deployed at Resolution Bay in Great Slave Lake. The Sondes were calibrated to the EXO and YSI 6 series user manual standards before being deployed on a mooring for up to 30 days to collect continuous measurements at 2-4 hour intervals.

Polyethylene Membrane Devices (PMDs) were used by GNWT-ENR to detect and measure a suite of parent and alkylated dissolved polycyclic aromatic hydrocarbons (PAHs). The PMDs passively sample water for dissolved hydrocarbons 3-4 times over a 30 day period during the open water season (MayOctober) at 3 sites (Rapids of the Drowned, Big Eddy and Resolution Bay) throughout the Slave River and Delta.

Surface grab water samples were collected by GNWT-ENR for nutrients approximately every 30 days at 3 sites (Rapids of the Drowned, Big Eddy and Resolution Bay) throughout the Slave River and Delta during the open water season (May-October) following ENR's NWT-wide Community based Monitoring program sampling protocols (2015). Samples were then immediately sent to the Taiga Environmental Laboratory in Yellowknife for processing and analysis.

Surface grab water samples were collected by GNWT-ENR for dissolved and total metals approximately every 30 days at 3 sites (Rapids of the Drowned, Big Eddy and Resolution Bay) throughout the Slave River and Delta during the open water season (May-October) following Taiga Environmental Lab protocols. Samples were then immediately sent to the Taiga Environmental Laboratory in Yellowknife for processing and analysis

Fish species most often caught by local fishers (Jackfish, Burbot, Whitefish, Goldeye, Walleye) were collected in collaboration with local fisherman as part of the Slave River and Delta Partnership (SRDP) community-based monitoring program. Nearly 2000 fish were sampled during the five years and subject to a detailed external assessment for the presence of structural deformities, tumors, and injuries. Where appropriate tissues were preserved for possible histological analysis. Fish were weighed and measured to allow calculation of condition factor.
2012 - 2014 
Fish internal anomalies

Fish bile polycyclic aromatic hydrocarbons

Fish mercury

Muskrat mercury

Moose stress

Water depth

Flow regime

Invertebrate density
Fish species most often collected by local fishers (Jackfish, Burbot, Whitefish, Goldeye, Walleye) were collected in collaboration with local fisherman as part of the SRDP community-based monitoring program. Nearly 2000 fish were sampled during the five years and subject to a detailed assessment of internal organs looking for abnormalities such as tumors, structural abnormalities and parasites. Internal organs were weighed to allow calculation of various organ/somatic indices.

Bile samples from over 1700 fish were collected during the three years as part of the SRDP communitybased monitoring program and analysed (Ohiozebau et al., 2015) spectrofluorometrically to measure concentrations of specific PAH classes.

Muscle samples from selected fish were analysed at the Toxicology Centre, U of S, for mercury concentrations. Samples were stored frozen, freeze-dried for 48 hours, ground to a powder with acidwashed utensils and analysed for total mercury by Direct Mercury Analysis (DMA-80, Milestone Inc.) A Certified Reference Material (Dogfish muscle, DORM-4) was analysed alongside sample, and yielded a recovery of $97 \pm 7 \%(\mathrm{n}=4)$.

Muscle tissue was analysed from 32 muskrats trapped in the Slave River Delta during January and February 2015. Samples were stored frozen, freeze-dried for 48 hours, ground to a powder with acidwashed utensils and analysed at the Toxicology Centre, U of S, for total mercury by Direct Mercury Analysis (DMA-80, Milestone Inc.). A Certified Reference Material (Dogfish muscle, DORM-4) was analysed alongside sample, and yielded a recovery of $97 \pm 7 \%(\mathrm{n}=4)$

Archived hair samples were analysed at the Toxicology Centre, U of S, for cortisol following protocols outlined in Macbeth et al. (2010). Hairs were washed with methanol, dried and ground to fine powder. They were immersed in methanol, vortexed and gently spun for $24 \mathrm{hr}$. They were then centrifuged and the supernatant was collected. The extracts were analysed with commercially available ELISA kits.

A bathymetric survey with sonar equipment was carried out in the summer by K-E. Lindenschmidt to determine water depths along the Slave River near Fort Smith and the Slave River Delta.

Daily flows were recorded by Environment Canada's Fitzgerald gauging station (Station \# 07NB001) throughout December to February.

Hester-Dendy samplers $\left(0.16 \mathrm{~m}^{2}\right.$ surface area) were affixed to paving stones (attached to a float) and placed in the Slave River (approximately 2 to $4 \mathrm{~m}$ depth) at one site near Fort Smith and at two sites in the Delta (Jean River and Steamboat channel). The samplers were retrieved 6 weeks later and the
$2011-2015$

$2011-2012 \& 2014$

$2013-2014$

$2011-2015$ 
Invertebrate taxa richness

Shannon Wiener index

Bird abundance

Fur-bearer abundance

Ice thickness

Dissolved oxygen under ice
Hester-Dendy samplers $\left(0.16 \mathrm{~m}^{2}\right.$ surface area) were affixed to paving stones (attached to a float) and placed in the Slave River (approximately 2 to $4 \mathrm{~m}$ depth) at one site near Fort Smith and at two sites in the Delta (Jean River and Steamboat channel). The samplers were retrieved 6 weeks later and the invertebrates collected, preserved, identified and counted by the SRDP community-based monitoring program.

Hester-Dendy samplers $\left(0.16 \mathrm{~m}^{2}\right.$ surface area) were affixed to paving stones (attached to a float) and placed in the Slave River (approximately 2 to $4 \mathrm{~m}$ depth) at one site near Fort Smith and at two sites in the Delta (Jean River and Steamboat channel). The samplers were retrieved 6 weeks later and the invertebrates collected, preserved, identified and counted by the SRDP community-based monitoring program.

Time lapse cameras were placed at two wetlands (Bear Trap Creek and Fred's Lake) by the SRDP community-based monitoring program. The camera at Bear Trap Creek took 12 photos at 5-minute intervals for one hour in the morning and again in the evening ( 24 photos per day). These two periods are believed to correspond to the times of highest animal activity. The camera at Fred's Lake took a single photo each hour from 7:00 am to 6:00 pm (12 photos per day). For each camera, the total number of waterfowl observed in all photos within a day was summed to give a daily total.

Review of GNWT - Fur Harvest database. The GNWT Fur Harvest database is the financial system that drives programming, tracking all fur/seal harvested in the NWT via a unique barcode identifier. The system maintains a link between the trappers/hunters and their harvest/production through the auction system to the buyer/manufacturer (end-user) for easy verification to establish origin.

Ice thicknesses were measured between February (near Fort Smith) and March by K-E. Lindenschmidt (Slave River Delta; see Das et al., 2015). Holes were drilled into the ice with a measuring staff. The staff had an L-bracket at one end that was lowered into the hole and hooked on the underside of the ice cover.

Dissolved oxygen (DO) concentration and saturation were measured by K-E. Lindenschmidt near Fort Smith at four locations in January using a Hoskin Scientific Pro Odo handheld DO and temperature meter 


\section{Appendix C.}

940 Refer to separate pdf file.

941

\section{Appendix D.}

Examples of the expert elicitation surveys showing the distribution of estimates on a scale of 1 to 10 . Each row represents a different scenario. Blue dots refer to expert's first estimate, whereas black dots refer to expert's second estimate (if desired) after the group reconvened to discuss their independent judgements.

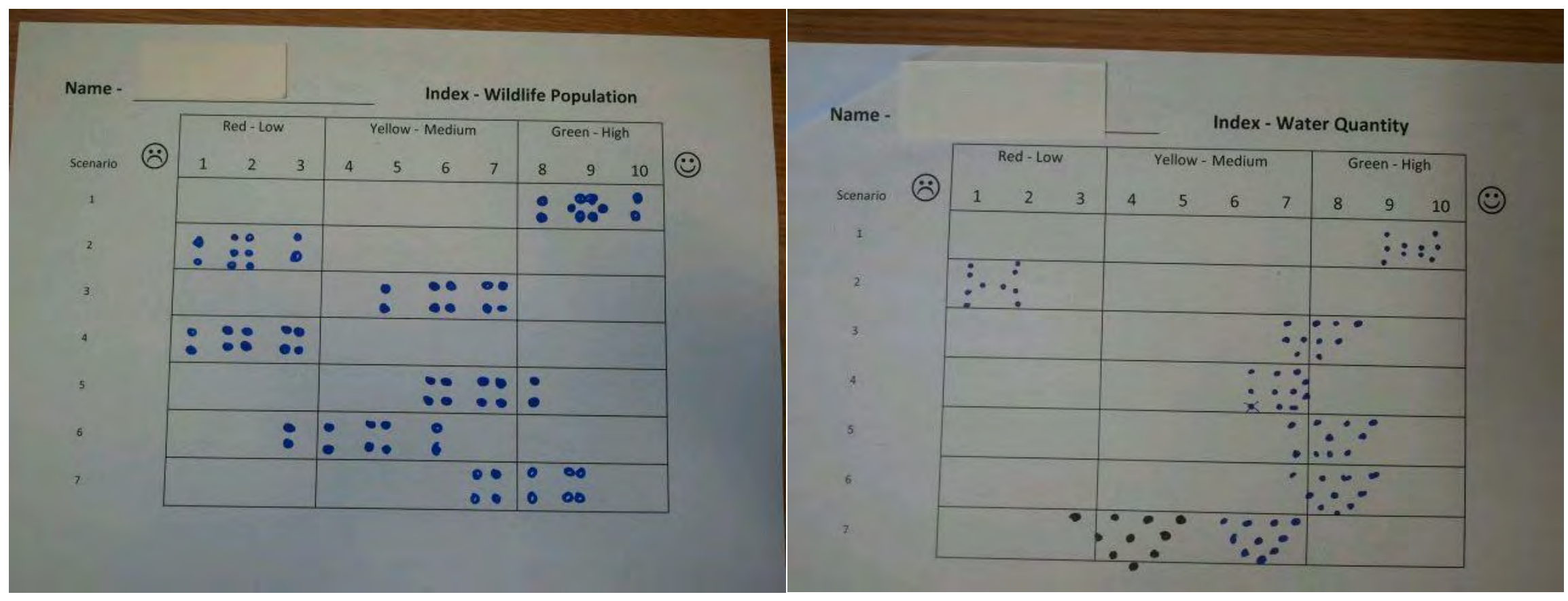




\section{Appendix E.}
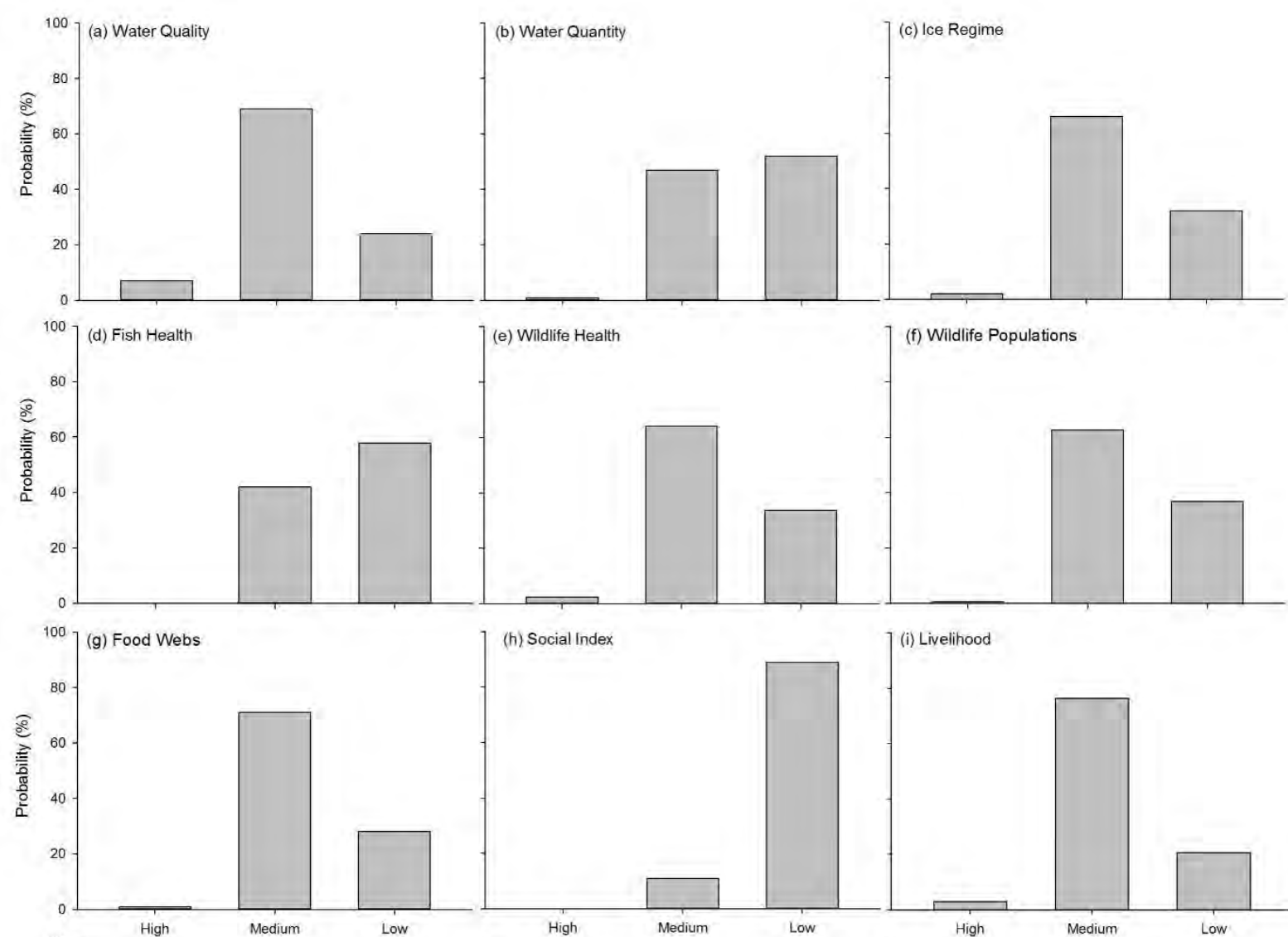

(h) Social Index

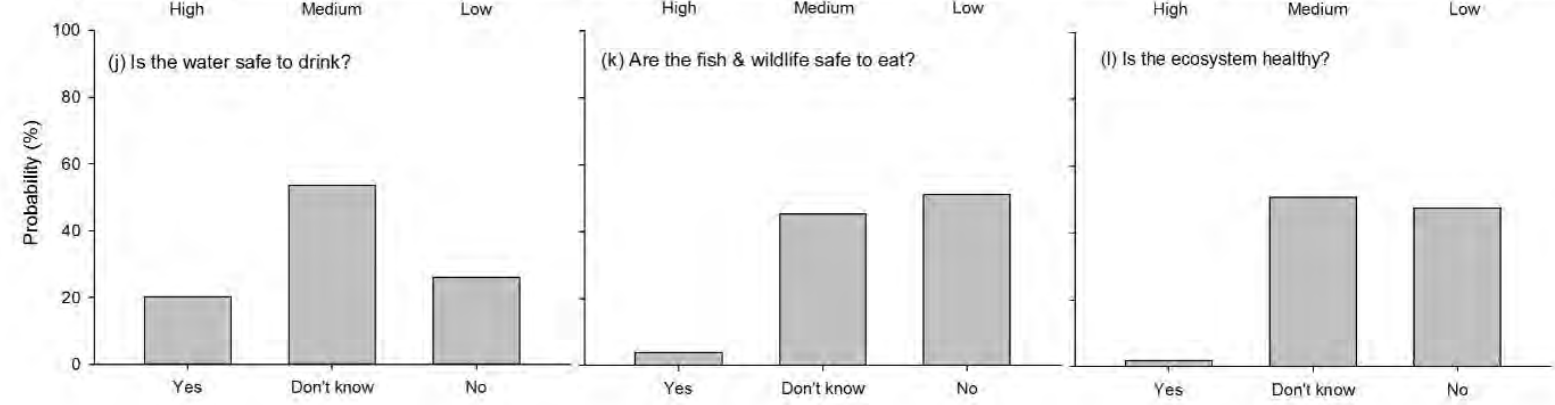

950 Fig. E1. Percent probabilities of the nine SRD environmental health indices $(a-i)$ and the three 951 guiding questions $(j-1)$ by the BBN model. The probabilities for this BBN were populated with 95213 experts that assessed 19 science based indicators and 22 traditional knowledge indicators. 
954 Table F1. The mean categorized states for 7 traditional knowledge (TK) and 7 scientific 955 knowledge (SK) indicators that are comparable in the Bayesian Belief Network.

\begin{tabular}{|c|c|c|c|}
\hline TK indicators & Mean state & SK indicators & Mean state \\
\hline $\begin{array}{l}\text { Physical appearance } \\
\text { of water }\end{array}$ & $\begin{array}{l}\text { Worse (water looks } \\
\text { worse now than in the } \\
\text { past) }\end{array}$ & Turbidity & Low $(<220$ NTU $)$ \\
\hline Fish aesthetics & $\begin{array}{l}\text { Worse (the fish look } \\
\text { worse now than in the } \\
\text { past) }\end{array}$ & $\begin{array}{l}\text { Fish external } \\
\text { anomalies }\end{array}$ & $\begin{array}{l}\text { Moderate }(1-5 \% \\
\text { anomalies on the fish } \\
\text { relative to all fish } \\
\text { examined) }\end{array}$ \\
\hline Water flow & $\begin{array}{l}\text { Less (there is less water } \\
\text { flow now than there was } \\
\text { in the past) }\end{array}$ & Flow regime & $\begin{array}{l}\text { Lower daily discharge } \\
(<3000 \mathrm{cms}-\text { forms } \\
\text { more black-ice covers })\end{array}$ \\
\hline Bird usage & $\begin{array}{l}\text { Less (I harvest and use } \\
\text { less birds now than I did } \\
\text { in the past) }\end{array}$ & Bird abundance & $\begin{array}{l}\text { Moderate (10 to } 50 \\
\text { daily counts of ducks) }\end{array}$ \\
\hline Harvesting & $\begin{array}{l}\text { Less (we rely less on } \\
\text { harvesting from the delta } \\
\text { now than in the past } \\
\text { because of changes to } \\
\text { the delta) }\end{array}$ & Fur-bearer abundance & $\begin{array}{l}\text { Moderate ( } 500 \text { to } 5000 \\
\text { trapped muskrats per } \\
\text { year) }\end{array}$ \\
\hline Air pocket density & $\begin{array}{l}\text { More (there are more air } \\
\text { pockets in the ice now } \\
\text { than in the past) }\end{array}$ & $\begin{array}{l}\text { Dissolved oxygen } \\
\text { concentration under } \\
\text { ice }\end{array}$ & $\begin{array}{l}\text { Saturated ( } 95-105 \%- \\
\text { a little more air pockets } \\
\text { in ice) }\end{array}$ \\
\hline Length of ice period & $\begin{array}{l}\text { Medium ( } 5.5-6.5 \\
\text { months - ice freeze up } \\
\text { happens the same as in } \\
\text { the past) }\end{array}$ & Ice thickness & $\begin{array}{l}\text { Thick }(>40 \mathrm{~cm}) \text { Small } \\
\text { truck travel possible) }\end{array}$ \\
\hline
\end{tabular}


Ashley, N., Barboza, P., Macbeth, B., Janz, D., Cattet, M., Booth, R., Wasser, S. (2011) Glucocorticosteroid concentrations in feces and hair of captive caribou and reindeer following adrenocorticotropic hormone challenge. General and Comparative Endocrinology 172, 382391.

Baumann, P.C., Mac, M.J., Smith, S.B., Harshbarger, J.C. (1991) Tumor frequencies in walleye (Stizostedion vitreum) and brown bullhead (Ictalurus nebulosus) and sediment contaminants in tributaries of the Laurentian Great Lakes. Canadian Journal of Fisheries and Aquatic Sciences 48, 1804-1810.

Brown, E.R., Hazdra, J.J., Keith, L., Greenspan, I., Kwapinski, J., Beamer, P. (1973) Frequency of fish tumors found in a polluted watershed as compared to nonpolluted Canadian waters. Cancer Research 33, 189-198.

CCME. (1999) Canadian Environmental Quality Guidelines (and updates). Canadian Council of Ministers of the Environment (CCME), Winnipeg, http://ceqg-rcqe.ccme.ca (viewed November 1, 2014).

Das, A., Sagin, J., Van der Sanden, J., Evans, E., McKay, H., Lindenschmidt, K.-E. (2015) Monitoring the freeze-up and ice cover progression of the Slave River. Canadian Journal of Civil Engineering 42, 1-13.

GoA, (2013) Best practice for building and working safely on ice covers in Alberta. Government of Alberta (GoA), Canada, https://work.alberta.ca/documents/WHSPUB sh010.pdf

Halbrook, R.S., Kirkpatrick, R.L., Scanlon, P.F., Vaughan, M.R., Veit, H.P. (1993) Muskrat populations in Virginia's Elizabeth River: physiological condition and accumulation of environmental contaminants. Archives of Environmental Contamination and Toxicology 25, 438-445.

Health Canada. (2007) Human health risk assessment of mercury in fish and health benefits of fish consumption. Government of Canada, Ottawa, http://www.hc-sc.gc.ca/fnan/pubs/mercur/merc fish poisson-eng.php (viewed November 1, 2014).

Karr, J.R. (1991) Biological integrity: a long-neglected aspect of water resource management. Ecological Applications 1, 66-84.

Kelly, E.N., Schindler, D.W., Hodson, P.V., Short, J.W., Radmanovich, R., Nielsen, C.C. (2010) Oil sands development contributes elements toxic at low concentrations to the Athabasca River and its tributaries. Proceedings of the National Academy of Sciences 107, 16178-16183.

Macbeth, B., Cattet, M., Stenhouse, G., Gibeau, M., Janz, D. (2010) Hair cortisol concentration as a noninvasive measure of long-term stress in free-ranging grizzly bears (Ursus arctos): considerations with implications for other wildlife. Canadian Journal of Zoology 88, 935-949. 
McLachlan, S., (2014) Water is a living thing. Environmental and Human Health Implications of the Athabasca Oil Sands for the Mikisew Cree First Nation and Athabasca Chipewyan First Nation in Northern Alberta. Phase Two report. University of Manitoba, Winnipeg, 242 pp.

Munkittrick, K., McMaster, M., Portt, C., Kraak, G.V.D., Smith, I., Dixon, D. (1992) Changes in maturity, plasma sex steroid levels, hepatic mixed-function oxygenase activity, and the presence of external lesions in lake whitefish (Coregonus clupeaformis) exposed to bleached kraft mill effluent. Canadian Journal of Fisheries and Aquatic Sciences 49, 1560-1569.

Ohiozebau, E., Tendler, B., Hill, A., Codling, G., Kelly, E., Giesy, J.P., Jones, P.D. (2015) Products of biotransformation of polycyclic aromatic hydrocarbons in fishes of the Athabasca/Slave River system, Canada. Environmental Geochemistry and Health 38, 577 591.

Sheffy, T., St. Amant, J. (1982) Mercury burdens in furbearers in Wisconsin. The Journal of Wildlife Management 46, 1117-1120.

Tipa, G., Teirney, L. (2003) A cultural health index for streams and waterways. Indicators for recognizing and expressing Maori values. Ministry for the Environment, Wellington, NZ, 68 pp. http://www.mfe.govt.nz

van den Heuvel, M.R., Power, M., MacKinnon, M., Dixon, D. (1999) Effects of oil sands related aquatic reclamation on yellow perch (Perca flavescens). II. Chemical and biochemical indicators of exposure to oil sands related waters. Canadian Journal of Fisheries and Aquatic Sciences 56, 1226-1233. 